\title{
The Association of Time to Organ Procurement on Short- and Long-Term Outcomes in Kidney Transplantation
}

\section{Eerola, Verner}

2021-03-08

Eerola , V , Helanterä , I, But , A , Lempinen , M , Mäkisalo , H , Nordin , A, Isoniemi , H \& Sallinen , V 2021 , ' The Association of Time to Organ Procurement on Short- and Long-Term Outcomes in Kidney Transplantation ', Clinical journal of the American Society of Nephrology , vol. 16 , no. 3 , pp. 427-436 . https://doi.org/10.2215/CJN.11420720

http://hdl.handle.net/10138/338540

https://doi.org/10.2215/CJN.11420720

unspecified

acceptedVersion

Downloaded from Helda, University of Helsinki institutional repository.

This is an electronic reprint of the original article.

This reprint may differ from the original in pagination and typographic detail.

Please cite the original version. 
Heading: The association of time to organ procurement on short- and longterm outcomes in kidney transplantation

Running head: The significance of procurement delay

Authors: Eerola, Verner, $\mathrm{BM}^{1}$; Helanterä, Ilkka, MD, $\mathrm{PhD}^{1}$; But, Anna, MSc, $\mathrm{PhD}^{2}$;

Lempinen, Marko, MD, PhD'; Mäkisalo, Heikki, Prof ${ }^{1}$; Nordin, Arno, MD, PhD'; Isoniemi, Helena, Prof ${ }^{1}$; Sallinen, Ville, MD, $\mathrm{PhD}^{1}$

ORCIDs:

Verner Eerola https://orcid.org/0000-0002-4925-156X

Ilkka Helanterä https://orcid.org/0000-0002-2954-2538

Ville Sallinen https://orcid.org/0000-0001-5394-4169

Affiliations: ${ }^{1}$ Department of Transplantation and Liver Surgery, Helsinki University Hospital and University of Helsinki, Helsinki, Finland

${ }^{2}$ Biostatistics consulting, Department of Public Health, University of Helsinki and Helsinki University Hospital, Helsinki, Finland

Corresponding author: Ville Sallinen, MD, PhD, Adj. Prof; Department of Transplantation and Liver Surgery, Helsinki University Hospital and University of Helsinki, Haartmaninkatu 4, 00290 Helsinki

+35894711 ville.sallinen@helsinki.fi

Word count for abstract: 235

Word count for text: 3,274 


\section{ABSTRACT}

Background and objectives: Transplant centers in Europe aim to minimize the time from brain death to organ procurement (procurement delay), but evidence to justify this is scarce. In the US procurement times are significantly longer. Our objective was to analyze how procurement delay associates with kidney allograft outcomes.

Design, setting, participants and measurements: Kidney transplantations from brain dead donors were retrospectively analyzed from the Finnish Kidney Transplant Registry and Scientific Registry of Transplant Recipients (SRTR) in the US. Multivariable models were adjusted with donor and recipient characteristics, and the relationship between procurement delay and outcomes were modelled with cubic spline functions.

Results: 2,388 and 101,474 kidney transplantations in Finland and the US were included, respectively. The median procurement delay was 9.8 hours (IQR 7.8-12.4) in Finland and 34.8 hours (IQR 26.3-46.3) in the US. A nonlinear association was observed between procurement delay and the risk of delayed graft function (DGF), with highest risk seen in short and very long procurement delays. In multivariable models, the lowest risk of DGF was associated with procurement delay between 20 and 50 hours. In multivariable models, longer procurement delay was linearly associated with lower risk of graft loss (HR 0.90 per one hour longer, $95 \% \mathrm{Cl} 0.88-0.92, \mathrm{p}<0.001)$. Acute rejection rates, for which data were only available from Finland, were not associated with procurement delay.

Conclusions: Longer procurement delay was associated with noninferior or even better kidney allograft outcomes. 


\section{INTRODUCTION}

Vast majority of organ donations are carried out in brain dead donors (donation after brain death, DBD). Brain death causes excretion of cytokines (so called 'cytokine storm'), which leads to initial tachycardia and hypertension followed by a hypotensive phase. Cytokines increase oxygen consumption and inflammatory activation, and may lead to increase in oxygen free radicals, which may cause cell damage ${ }^{1-4}$. Furthermore, hypotensive phase may decrease oxygen supply to already compromised cells. This is further supported by data from animal experiments, in which prolongation of time after brain death has led to increased inflammation, coagulation and organ dysfunction in kidneys $s^{1,5-7}$. In addition, organ function is thought to deteriorate and eventually fail if procurement is excessively postponed. Because of these detrimental effects of brain death, it is generally considered that organs should be procured as soon as possible after brain death and European practises aim to minimize time from brain death to organ cold perfusion (procurement delay). However, usually the 'cytokine storm' settles within hours and brain dead organ donors are hemodynamically stable thereafter ${ }^{8}$.

Contrary to these beliefs, some retrospective studies have demonstrated an advantageous correlation of longer time before organ retrieval in kidney transplant early function ${ }^{9,10}$ and survival $^{9-11}$. These studies may have attributed to the increasingly longer procurement times in the US, although retrospective and some having small cohort size $e^{9,11}$ and lack of adjustment for confounders ${ }^{9}$. As such, procurement delays vary greatly between countries and optimal time is currently unknown. Knowing the ideal procurement delay has great implications in transplantation logistics, work shifts, resource allocation, and ultimately in patient and graft survival.

The aim of this study was to examine the association of procurement delay on kidney allograft early function and survival in two different transplant populations with different median times from brain death to organ procurement (Finland and the US). 


\section{MATERIALS AND METHODS}

\section{Donors and patients}

Consecutive deceased donor kidney transplantations in Finland from June 2004 to

December 2017 were included and followed until death, graft loss, or August 2018. The data were collected from the Finnish Kidney Transplant Registry and from donor medical documents. Only donors, in which the procurement was done within Finland were included, and kidneys that were received from other Scandiatransplant countries were excluded. Similarly, kidneys procured in Finland, but sent for transplantation to another country were excluded. All transplantations in Finland are performed in the Helsinki University Hospital, wherefrom a team of transplant surgeons is also responsible for the procurement surgery in the whole country. All donations were from donors after brain death (DBD). No donation after cardiac death (DCD) occurred in Finland during the study period and kidney transplantations from a living donor were not included.

Kidney transplantations recorded in Scientific Registry of Transplant Recipients (SRTR) database in the US between January 2008 to August 2018 were included. This study used data from the Scientific Registry of Transplant Recipients (SRTR). The SRTR data system includes data on all donor, wait-listed candidates, and transplant recipients in the US, submitted by the members of the Organ Procurement and Transplantation Network (OPTN). The Health Resources and Services Administration (HRSA), U.S. Department of Health and Human Services provides oversight to the activities of the OPTN and SRTR contractors. Standard Analysis Files (Q3 2018 release) and DEATHS file were used. Data of recipients were linked with donor data using unique donor identification numbers. Only kidneys transplanted from DBD donors were included, and kidneys from DCD or living donors were excluded.

This study was approved by the Institutional Review Board of Helsinki University Hospital (HUS/459/2018) and SRTR. The clinical and research activities being reported are consistent 
with the Principles of the Declaration of Istanbul as outlined in the 'Declaration of Istanbul on Organ Trafficking and Transplant Tourism'.

The following donor variables were collected for both Finnish and US cohort: donor gender and age, the time of declaration of brain death, the start time of cold perfusion in organ procurement surgery, cause of death, body mass index, race, use of kidney machine perfusion, resuscitation, laboratory results, donor history of hypertension, diabetes, smoking, alcohol and drug use, hepatitis $\mathrm{C}$ status, and number of organs transplanted from the same donor in addition to kidneys. Data on discarded organs was not available for the purpose of this study. Regarding the recipient and transplantation, the following data were collected: recipient sex and age, cause of kidney failure, body mass index, history of hypertension, time in dialysis, maximum panel-reactive antibody status, human leukocyte antigen mismatches, graft cold ischemia time, delayed graft function, rejection episodes and graft survival. Kidney Donor Profile Index (KDPI) was also calculated from these variables according to Organ Procurement and Transplantation Network/ United Network for Organ Sharing mapping table of $2017^{12}$, for both Finnish and US donors. KDPI is calculated based on donor age, BMI, hypertension, diabetes, kidney function, cause of death, race, and status of hepatitis $C$ virus. When KDPI was included in the models, the donor factors used to calculate KDPI were left out of the model due to possible multi-collinearity. Procurement delay was defined as the time from the declaration of brain death to the start of in situ cold perfusion.

\section{Endpoints}

Long-term dependent outcome measure was graft survival in which graft failure was defined as the need of retransplant, return to dialysis, or recipient death. Delayed graft function (DGF) was defined as the need for dialysis during the first week after transplantation. Data regarding acute rejection (AR), available only for the Finnish cohort, was defined as the need for rejection treatment in a biopsy-proven borderline or acute cellular or antibody-mediated rejection. 


\section{Statistical analysis}

For presentation of the data, transplantations were divided into quartiles based on the length of procurement delay. We report frequencies and percentage for categorical data and median and interquartile range (IQR) for continuous data. Number of patients with missing values are stated in the table.

In the main analysis, we assessed the association between procurement delay (hours) and DGF, as well as procurement delay and kidney graft survival by fitting unadjusted and multivariable logistic regression models and Cox proportional hazards models, respectively. In multivariable analysis, we controlled for potential confounders, which we identified based on directed acyclic graphs (DAG) $)^{13}$. For both DGF and graft survival, we considered kidney donor profile index, recipient age (years), diabetes and dialysis vintage (months) as confounders (Supplemental Figure 1). Of these all except diabetes were used in analysis as continuous variables. All models were fitted on the complete-cases data formed by excluding observations with missing data on response variables or/and covariates. To account for clustering nature of the data due to relationship between kidneys from the same donor, we calculated cluster-robust standard errors of the estimates by using Huber-White method ${ }^{14}$. As the logistic regression and Cox models involve the assumption of linearity for the continuous data, we used restricted cubic spline function to account for potentially non-linear association between the outcome of interest and procurement delay, KDPI, recipient age and dialysis vintage. We tested for non-linearity and modelled the associations either as linear or non-linear. Linear associations between procurement delay and the outcome of interest were reported using the odds ratio $(\mathrm{OR})$ or hazard ratio $(\mathrm{HR})$ with $95 \%$ confidence interval $(\mathrm{Cl})$, as appropriate. The associations assessed with spline function were reported by plotting the predicted probability of DGF or the predicted relative hazard of graft survival as a function of procurement delay. As the Cox regression model is based on the assumption of proportional hazards, we tested for the potential non-proportionality. We accounted for the non- 
proportionality by splitting the follow-up time into smaller intervals and by assessing timevarying coefficients or / and including interactions with follow-up time.

In addition, we performed several sensitivity analyses using the US data, which included enough observations for stratified analysis. We checked for consistency of the results with respect to implementation of kidney allocation system (KAS) in December 2014, number of organs transplanted from the same donor (organ yield), and cold ischemia time by dividing observations into strata and repeating the main analysis within each stratum. The number of strata varied between two for KAS (before and after KAS) to four for organ yield (only kidney(s), kidney(s) and one, two or more than two other organs) and cold ischemia time $(<12,12-18,18-24,>=24$ hours $)$.

We set the significance level at $5 \%$. All analyses were performed using either IBM SPSS version 25 for Windows (Armonk, NY), or R software, including survival and rms packages ( $R$ Foundation for Statistical Computing, Vienna, Austria).

\section{RESULTS}

\section{Patients}

Between $1^{\text {st }}$ June 2004 and $31^{\text {st }}$ December 2017, 2,660 kidneys were procured in Finland, from which 74 were discarded and 198 were sent abroad, leaving 2,388 kidney transplantations from 1356 donors in the final analyses.

Between $1^{\text {st }}$ January 2008 and $31^{\text {st }}$ August 2018, 125,595 kidney transplantations from 72,290 deceased donors were recorded in SRTR database. Altogether 20,874 kidney transplantations, which were from DCD donors, were excluded. Furthermore, procurement delay could not be determined in 2,889 kidney transplant recipients because of missing date of brain death and thus these were excluded from the analysis. In addition, we excluded 349 transplantations with extreme $(>120 \mathrm{~h})$ procurement delay values. Final cohort from the US SRTR database included 101,474 kidney transplantations. 
Basic donor and recipient characteristics among the cohorts from Finland and the US are depicted in Table 1. The median procurement delay was 9.8 hours (interquartile range (IQR) 7.8 - 12.4) in Finland and 34.9 hours (IQR 26.3 - 46.5) in the US (Figure 1).

Patients were divided into quartiles based on procurement delay. There were significant differences in basic donor and recipient characteristics between the delay quartiles (Table 2). Outcomes of patients, divided into quartiles, are presented in Table 3.

\section{Short-term outcomes}

Complete DGF response and confounder data were available on 2371 (99\% of the initial cohort) and 89,337 (88\%) transplantations in the Finnish and the US cohort, respectively. In the Finnish cohort, unadjusted analysis on the association between procurement delay and the probability of DGF demonstrated a linear relationship (crude $\mathrm{OR}=0.85,95 \% \mathrm{Cl} 0.77-0.95$, $p=0.003 ; p=0.67$ for non-linearity, Figure 2A), which, however, attenuated after adjustment (adjusted $\mathrm{OR}=0.99,95 \% \mathrm{Cl} 0.89-1.11, \mathrm{p}=0.88$ ). In contrast, a strongly non-linear relationship was observed between procurement delay and the probability of DGF in the US cohort both in unadjusted (Figure 2B, $\mathrm{p}<0.001$ for non-linear relationship) and multivariable analysis (Figure $2 \mathrm{C}, \mathrm{p}<0.001$ ). The lowest probability of DGF was associated with procurement delay between 20 and 50 hours, with higher probability in shorter or very long procurement delays.

\section{Acute rejection}

Acute rejection rates were not affected by procurement delay in Finnish cohort (Table 3, $\mathrm{OR}=0.92,95 \% \mathrm{Cl} 0.81-1.05, \mathrm{p}=0.22$ in unadjusted logistic regression). Data concerning acute rejections were not available for the US cohort.

\section{Graft survival}

Complete response and confounder data for graft survival analyses were available on 2371 (99\% of the initial cohort) and $89,814(89 \%)$ transplantations in the Finnish and the US cohort, respectively (Figure 3). Unadjusted graft survival rates in different quartiles of procurement delay are presented in Table 3 and Figure 3. In unadjusted analyses, we found 
a non-linear association between procurement delay and kidney graft survival in the Finnish cohort (Figure 4, $p=0.005$ for non-linearity) but a linear association in the US cohort (Figure $4, p=0.24$ for non-linearity), both showing lower hazard for graft loss associated with longer procurement delay. After adjustment for confounders, non-linearity persisted in the Finnish cohort ( $p=0.033$ ) but was not present in the US cohort $(p=0.67$ for non-linearity). In the US cohort, modelling a linear association yielded the crude and adjusted HRs of $0.90(95 \% \mathrm{Cl}$ $0.88-0.92, \mathrm{p}<0.001)$ and $0.93(95 \% \mathrm{Cl} 0.92-0.95, \mathrm{p}<0.001)$ per one hour longer procurement delay, respectively. No significant interactions were found between procurement delay and recipient characteristics $(p=0.054-0.73, p=0.41-0.98), \operatorname{KDPI}(p=0.96, p=0.50)$, or cold ischemia time $(p=0.14, p=0.41)$ for the Finnish and the US cohort, respectively.

In the unadjusted and multivariable Cox models fitted to the Finnish cohort, we found the assumption of proportional hazards to hold for all variables except dialysis vintage. In the unadjusted and multivariable Cox models fitted to the US cohort, we found nonproportionality for all variables including procurement delay. After accounting for nonproportionality by splitting the follow-up time and including interaction between dialysis vintage and follow-up time, a non-linear association between procurement delay and graft survival persisted ( $p=0.027$ for non-linearity) in the Finnish cohort. In the US cohort, the association between procurement delay and hazard attenuated over time (Supplemental Table 1). After restricting the follow-up to 1.5 years, we found the assumption of proportional hazards to hold and the association to be non-linear in the unadjusted analysis $(p=0.036)$ but linear in the multivariable analysis $(\mathrm{HR}=0.90,95 \% \mathrm{Cl} 0.87-0.93)$.

In the US cohort, we performed sensitivity analysis in ten strata and found the results to be similar to that of the main analysis in all except two strata (Supplemental Figures 2-12). Before the implementation of the KAS in 2014, the median procurement delay was 31 hours (IQR 24-40), compared to 42h (IQR 32-55) after the implementation of KAS. However, in sensitivity analyses the association between procurement delay and graft outcomes remained similar in both groups (Supplemental Figures 2-3). When the number of organs 
transplanted from the same donor was taken into account, no interaction was recorded between the organ yield and procurement delay $(p=0.37-0.94)$ in either of the cohorts. In the sensitivity analysis within each stratum, the findings remained similar if maximum two other organs were transplanted in addition to kidneys from the same donor (Supplemental Figures 4-7). In the stratum including kidney transplants procured with more than two other transplanted organs, we found no statistically significant association between procurement delay and hazard $(\mathrm{HR}=0.96,95 \% \mathrm{Cl} 0.91-1.00, \mathrm{p}=0.08)$. When restricting cold ischemia time to $18-24$ hours, we observed a non-linear relationship $(p=0.04)$ between procurement delay and hazard in multivariable analysis (Supplemental Figure 11).

\section{DISCUSSION}

In this study of two countries, longer procurement delay was not associated with lower longterm kidney allograft survival. On the contrary, very short delay ( $<8$ hours) was associated with worse graft survival, whereas increasing delay was associated with improved graft survival to a smaller extent, but without apparent upper limit. Of note, the median procurement delay in the longest delay quartile in Finland (15 hours) was shorter than the median delay in the shortest quartile in the US (21 hours). The probability of DGF was lowest between 20 and 50 hrs of procurement delay, whereas procurement delay was not associated with AR rates in Finnish transplants. These results together imply a sweet spot of approximately $24-48$ hours after brain death for organ procurement.

In concordance with our results, three earlier studies reported association of increasing procurement delay with improved kidney graft survival ${ }^{9-11}$, while one smaller study did not find an association ${ }^{15}$. Two of these studies found no association between procurement delay and the risk of DGF in multivariable models ${ }^{10,11}$, whereas in our study the risk of DGF was higher with very long procurement delays. AR was not affected by procurement delay ${ }^{10,11}$, 
and none of the studies reported any benefits of shorter delay ${ }^{9-11,15}$. All studies conducted have been retrospective and therefore possibly limited by the same confounding factors. Although the findings in the current study are not novel, our study confirmed the findings of the previous studies in the largest cohort to date across two continents, with statistical methods taking account the nonlinear association between procurement delay and graft outcomes. We also demonstrate that the association between slightly better outcomes and longer procurement delay remains also in the current era, where times from brain death to organ procurement in the US are longer than in the earlier studies.

Median procurement delays vary markedly in the reported series. Shortest procurement delays were reported in Germany, median 8 hours $^{9}$, and longest in the US (median 24 hours $)^{10}$. Interestingly, Nijboer et al $^{10}$ analyzed US data from 1994 to 2007, whereas our data included years 2008 - 2018, showing that the median delay increased from 24 hours to 35 hours between these two eras in the US. The reasons behind the different delays in different countries and the increase in median delay in the US over time seem logistics-driven, but no clear additional harm was observed from prolonging procurement over the years.

One of the concerns of longer procurement delay is the potential deterioration of the donor and potential loss of viable organs. However, evidence to justify this concern is scarce and possibly derives from hemodynamically unstable donors with insufficient donor management protocols in the past. A study from Brazil found over 30-hour procurement time to be a possible risk factor to losing a donor ${ }^{16}$, whereas studies from the US found no difference in organ procurement rates up to over 60 hours after brain death ${ }^{8,17}$.

In heart transplantation, prolonged donor management time, but not time after brain death, has been associated with poorer outcome ${ }^{18}$. However, newer studies found no significant survival difference in hearts ${ }^{19}$, and a positive association of longer delay with better lung acute rejection- and bronchiolitis obliterans-free survival ${ }^{20}$. Interestingly no animal studies favoring longer procurement were found. 
A limitation of this study is that causality cannot be established from this observational registry analysis. Also due to retrospective and non-randomized nature of the study, it is susceptible to residual confounding and distortion of the association due to non-random allocation. The latter cannot be controlled using standard statistical methods, such as model adjustment ${ }^{21}$. Moreover, the studied associations appear to be more complex than in the simplified DAG that was used to identify confounders. In fact, some covariates are likely to play both the role of confounder and mediator of the effect of interest. Only kidney transplantations were analyzed in this study, and further studies are needed to assess correlation of procurement delay on other organs. There are several strengths also. We tried to limit the bias by conducting multivariable analyses using multiple confounding variables, which should account for better quality organs distributing unevenly between procurement times. Another strength is the sample size, which is five times larger than in the biggest earlier report ${ }^{10}$. Analysis of two different cohorts from two continents with different organ procurement practices and large differences in times from brain death to organ procurement gives a broader perspective to this effect, although the relatively small sample size of the Finnish cohort limits our possibilities to adjust for confounding factors in this cohort in all analyses. The optimal delay seems to be over 8 hours, but procurement delays up to 50 hours do not seem harmful for kidney transplants. When considering the optimal timing of the organ procurement, multiple factors have to be taken into account. In the current data, longer procurement delays were associated with increasing number of organs transplanted from the same donor, which is indeed expected as the logistics of both the organ procurement and allocation takes more time. In addition to medical factors related to the outcome of the grafts, although beyond the scope of the current study, also economical costs of prolonging the procurement operation have to be considered.

The mechanisms, by which longer procurement delay is associated with better graft survival can only be speculated. Brain death (and its associated cytokine storm) and ischemia may be considered as 'hits' that affect kidney allografts negatively. In this two-hit theory, it could 
be beneficial for the kidney to recover from the first hit (brain death) before it is exposed to the second hit (ischemia). Also protective mechanisms, such as heat-shock proteins and systemic mediators upregulated by ischemia could play a role in allograft preservation ${ }^{22-24}$. However, no serial data about the trend in urine output or kidney function in the donors were available, limiting our possibilities to further explore this hypothesis. 


\section{DISCLOSURES}

VS reports receiving grants from Academy of Finland, Finnish Cancer Foundation

(Syöpäsäätiö), Finnish Surgical Society, Finska Läkaresällskapet, and the Finnish

Gastroenterological Society; lecturing fees from the City of Vantaa, Finnish

Gastroenterological Society, and the University of Helsinki outside the submitted work. IH reports receiving grants from Finska Läkaresällskapet and Helsinki University Hospital, and consulting fees from Novartis, Astellas and Aplagon outside the submitted work. Other authors of this manuscript report no conflicts of interest to disclose. 


\section{ACKNOWLEDGMENTS / FUNDING}

We thank the transplantation coordinators Siv Ansa, Eero Hartikka, Heikki Norio, Carola Schauman, and Leena Toivonen from Helsinki University Hospital and Nina Ask for their help with the transplantation registry of Finland.

This study was funded by grants from Helsinki University Hospital (VTR to HI, VS, and IH) and Finska Läkaresällskapet (to IH and VS). For the remaining authors no funding was declared.

The data reported here have been supplied by the Hennepin Healthcare Research Institute (HHRI) as the contractor for the Scientific Registry of Transplant Recipients (SRTR). The interpretation and reporting of these data are the responsibility of the author(s) and in no way should be seen as an official policy of or interpretation by the SRTR or the U.S. Government. 


\section{TABLE OF CONTENTS OF SUPPLEMENTAL MATERIAL}

Directed acyclic graph (DAG) 29

Sensitivity analyses. 30

Table 1. US cohort, time dependent hazard ratio..................................... 30

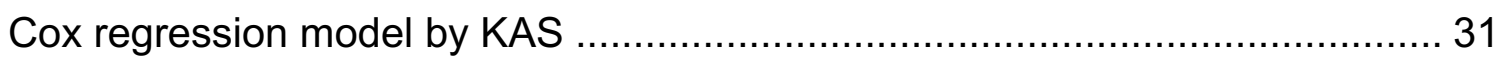

Cox regression model by organ yield ................................................ 33

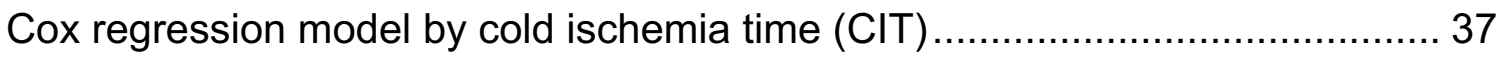




\section{REFERENCES}

1. van der Hoeven JAB, Ter Horst GJ, Molema G, de Vos P, Girbes ARJ, Postema F, Freund RL, Wiersema J, van Schilfgaarde R, Ploeg RJ. Effects of Brain Death and Hemodynamic Status on Function and Immunologic Activation of the Potential Donor Liver in the Rat. Ann Surg. 2000;232(6):804.

2. van Der Hoeven JAB, Molema G, Ter Horst GJ, Freund RL, Wiersema J, van Schilfgaarde R, Leuvenink HGD, Ploeg RJ. Relationship between duration of brain death and hemodynamic (in)stability on progressive dysfunction and increased immunologic activation of donor kidneys. Kidney Int. 2003;64(5):1874-1882.

3. Bos EM, Leuvenink HGD, van Goor H, Ploeg RJ. Kidney grafts from brain dead donors: Inferior quality or opportunity for improvement? Kidney Int. 2007;72(7):797805.

4. Pratschke J, Weiss S, Neuhaus P, Pascher A. Review of nonimmunological causes for deteriorated graft function and graft loss after transplantation. Transpl Int. 2008;21(6):512-522.

5. Pratschke J, Wilhelm MJ, Laskowski I, Kusaka M, Beato F, Tullius SG, Neuhaus P, Hancock WW, Tilney NL. Influence of Donor Brain Death on Chronic Rejection of Renal Transplants in Rats. J Am Soc Nephrol. 2001; 12: 2474-2481.

6. Schuurs TA, Morariu AM, Ottens PJ, 't Hart NA, Popma SH, Leuvenink HGD, Ploeg RJ. Time-dependent changes in donor brain death related processes. Am J Transplant. 2006;6(12):2903-2911.

7. Morariu AM, Schuurs TA, Leuvenink HGD, van Oeveren W, Rakhorst G, Ploeg RJ. Early Events in Kidney Donation: Progression of Endothelial Activation, Oxidative Stress and Tubular Injury After Brain Death. Am J Transplant. 2008;8(5):933-941.

8. Lytle FT, Afessa B, Keegan MT. Progression of Organ Failure in Patients Approaching 
Brain Stem Death. Am J Transplant. 2009;9:1446-1450.

9. Kunzendorf U, Hohenstein B, Oberbarnscheid M, Muller E, Renders L, Schott GE, Offermann G. Duration of Donor Brain Death and its Influence on Kidney Graft Function. Am J Transplant. 2002;2(3):292-294.

10. Nijboer WN, Moers C, Leuvenink HGD, Ploeg RJ. How important is the duration of the brain death period for the outcome in kidney transplantation? Transp/ Int. 2010;24(1):14-20.

11. Ergün M, Özdemir-van Brunschot DMD, Donders RART, Hilbrands LB, Hoitsma AJ, Warlé MC. Prolonged Duration of Brain Death was Associated with Better Kidney Allograft Function and Survival: A Prospective Cohort Analysis. Ann Transplant. 2019;24:147-154.

12. Organ Procurement and Transplantation Network. KDRI to KDPI Mapping Table of 2017. https://optn.transplant.hrsa.gov/media/2150/kdpi_mapping_table.pdf. Accessed March 8, 2020.

13. Suttorp MM, Siegerink B, Jager KJ, Zoccali C, Dekker FW. Graphical presentation of confounding in directed acyclic graphs. Nephrol Dial Transplant. 2015;30(9):14181423.

14. White H. Maximum Likelihood Estimation of Misspecified Models. Econometrica. $1982 ; 50(1): 1$

15. Muruve NA, Helling TS, Luger AM, Martinez J, Nelson PW, Pierce GE, Ross G, Shield III CF, Warady BA, Aeder MI, Bryan CF. Effect of donor brain-death duration on graft outcome. Transplant Proc. 2001;33(6):2980-2981.

16. Westphal GA, Slaviero TA, Montemezzo A, Lingiardi GT, de Souza FCC, Carnin TC, Soares DR, Hachiya AH, Ferraz LL, de Andrade J . The effect of brain death protocol duration on potential donor losses due to cardiac arrest. Clin Transplant. 
2016;30(11):1411-1416.

17. Inaba K, Branco BC, Lam L, Salim A, Talving P, Plurad D, Green DJ, Demetriades D. Organ donation and time to procurement: late is not too late. $J$ Trauma. 2010;68(6):1362-1366.

18. Cantin B, Kwok BWK, Chan MCY, Valantine HA, Oyer PE, Robbins RC, Hunt SA. The impact of brain death on survival after heart transplantation: time is of the essence. Transplantation. 2003;76(9):1275-1279.

19. Jawitz OK, Raman V, Barac YD, Anand J, Patel CB, Mentz RJ, DeVore AD, Milano C. Influence of donor brain death duration on outcomes following heart transplantation: A United Network for Organ Sharing Registry analysis. J Thorac Cardiovasc Surg. April 2019.

20. Jawitz OK, Raman V, Barac Y, Mulvihill MS, Moore C, Choi AY, Hartwig M, Klapper J. Impact of Donor Brain Death Duration on Outcomes After Lung Transplantation. Annals of Thoracic Surgery. 2019: (108) 1519-1526.

21. Austin PC, Stuart EA. The performance of inverse probability of treatment weighting and full matching on the propensity score in the presence of model misspecification when estimating the effect of treatment on survival outcomes. Stat Methods Med Res. 2017;26(4):1654-1670.

22. Nijboer WN, Schuurs TA, Van Der Hoeven JAB, Fekken S, Wiersema-Buist J, Leuvenink HGD, Hofker S, Homan van der Heide JJ, van Son WJ, Ploeg RJ. Effect of brain death on gene expression and tissue activation in human donor kidneys. Transplantation. 2004;78(7):978-986.

23. Schuurs TA, Gerbens F, van Der Hoeven JAB, Ottens PJ, Kooi KA, Leuvenink HGD, Hofstra RMW, Ploeg RJ. Distinct transcriptional changes in donor kidneys upon brain death induction in rats: Insights in the processes of brain death. Am J Transplant. 
2004;4(12):1972-1981.

24. Saat TC, Susa D, Roest HP, Kok NFM, van den Engel S, ljzermans JNM, de Bruin RWF. A comparison of inflammatory, cytoprotective and injury gene expression profiles in kidneys from brain death and cardiac death donors. Transplantation. 2014;98(1):15-21. 


\section{FIGURE LEGENDS}

Figure 1. Distribution of time from declaration of brain death to cold perfusion in Finnish organ donors from June 2004 to December 2017 and SRTR organ donors from January 2008 to August 2018.

Figure 2. The estimated probability (black line) of delayed graft function as a function of procurement delay when assessed using unadjusted $(A, B)$ and multivariable $(C)$ logistic regression model with restricted cubic spline function. Grey area corresponds to $95 \%$ confidence band.

A) Finnish cohort: $p=0.67$ for non-linear association.

B) US cohort: $p<0.001$ for non-linear association.

C) US cohort: $p<0.001$ for non-linear association. Predicted values were calculated by setting confounder values to their median $(\mathrm{KDPI}=45$, recipient age $=53$ years, dialysis vintage $=45.57$ months) or the most frequent category (no diabetes).

Figure 3. Graft survival of kidney transplants in Finland from June 2004 to December 2017 and the US from January 2008 to August 2018 by quartiles of time from brain death to cold perfusion (procurement delay in hours $(\mathrm{h})$ ). Outcome is defined as death, return to dialysis, or retransplantation.

Figure 4. The estimated relative hazard (black line) of graft failure or death as a function of procurement delay when assessed using unadjusted Cox regression model with restricted cubic spline function. Grey area corresponds to $95 \%$ confidence band, $p=0.005$ for non-linear association in Finnish cohort and $p=0.11$ for non-linear association in the US cohort. 


\section{TABLES}

Table 1. Characteristics of donors and kidney transplantations in Finland from June 2004 to December 2017 and the US from January 2008 to August 2018.

\begin{tabular}{|c|c|c|c|c|}
\hline Baseline characteristics & $\begin{array}{c}\text { Finland } \\
\text { 2,388 kidney } \\
\text { transplantations } \\
1,311 \text { donors }\end{array}$ & $\begin{array}{c}\text { US } \\
\text { 101,474 kidney } \\
\text { transplantations } \\
58,792 \text { donors }\end{array}$ & $\begin{array}{l}\text { Missing } \\
\text { Finland } \\
\mathrm{n}(\%)\end{array}$ & $\begin{array}{c}\text { Missing } \\
\text { US } \\
\mathrm{n}(\%)\end{array}$ \\
\hline $\begin{array}{l}\text { Donor time from brain death to } \\
\text { organ perfusion, median (IQR), } \\
\text { hours }\end{array}$ & $9.8(7.8-12.4)$ & $34.8(26.3-46.3)$ & 0 & 0 \\
\hline Donor age, median (IQR), years & $55(45-63)$ & $37(23-50)$ & 0 & 0 \\
\hline Donor BMI, median (IQR), $\mathrm{kg} / \mathrm{m}^{2}$ & $24.8(23.1-27.7)$ & $26.1(22.6-30.5)$ & $\begin{array}{l}2 \\
(0.2 \%)\end{array}$ & 0 \\
\hline Donor gender, male & $674(56 \%)$ & $35,396(60 \%)$ & 0 & 0 \\
\hline $\begin{array}{l}\text { Donor cardiac arrest prior to } \\
\text { brain death }\end{array}$ & $229(18 \%)$ & $4,427(8 \%)$ & 0 & $\begin{array}{l}9 \\
(0.0 \%)\end{array}$ \\
\hline $\begin{array}{l}\text { Donor medical conditions, } \\
\text { Hypertension } \\
\text { Diabetes }\end{array}$ & $\begin{array}{l}377(29 \%) \\
57(4 \%)\end{array}$ & $\begin{array}{l}15,481(26 \%) \\
4,031(7 \%) \\
\end{array}$ & $\begin{array}{l}0 \\
0\end{array}$ & $\begin{array}{l}375 \\
(0.6 \%) \\
0\end{array}$ \\
\hline $\begin{array}{l}\text { Donor cause of death, } \\
\text { Cerebrovascular accident } \\
\text { Trauma } \\
\text { Anoxia } \\
\text { Other }\end{array}$ & $\begin{array}{l}896(68 \%) \\
340(26 \%) \\
37(3 \%) \\
75(6 \%)\end{array}$ & $\begin{array}{l}17,822(30 \%) \\
22,009(37 \%) \\
17,447(30 \%) \\
1,514(3 \%)\end{array}$ & 0 & 0 \\
\hline $\begin{array}{l}\text { Donor need of inotropic } \\
\text { medication }\end{array}$ & $1,210(92 \%)$ & $30,355(52 \%)$ & 0 & $\begin{array}{l}123 \\
(0.2 \%)\end{array}$ \\
\hline $\begin{array}{l}\text { Donor creatinine, median (IQR), } \\
\mathrm{mg} / \mathrm{dl}\end{array}$ & $0.7(0.5-0.8)$ & $1.0(0.7-1.3)$ & $\begin{array}{l}1 \\
(0.1 \%)\end{array}$ & 0 \\
\hline $\mathrm{KDPI}^{\mathrm{a}}$, median $(\mathrm{IQR})$ & $60(36-80)$ & $44(20-69)$ & $\begin{array}{l}4 \\
(0.3 \%)\end{array}$ & $\begin{array}{l}436 \\
(0.7 \%)\end{array}$ \\
\hline $\begin{array}{l}\text { Donor organ yield }{ }^{b} \text {, median } \\
\text { (IQR) }\end{array}$ & $3(2-3)$ & $4(3-4)$ & 0 & 0 \\
\hline $\begin{array}{l}\text { Cold ischemia time, median } \\
\text { (IQR), hours }\end{array}$ & $20.3(17.2-23.4)$ & $15.5(10.4-21.9)$ & $\begin{array}{l}7 \\
(0.3 \%)\end{array}$ & $\begin{array}{l}1,985 \\
(2 \%)\end{array}$ \\
\hline $\begin{array}{l}\text { Recipient age, median (IQR), } \\
\text { years }\end{array}$ & $53(42-62)$ & $54(42-63)$ & 0 & 0 \\
\hline $\begin{array}{l}\text { Recipient BMI, median (IQR), } \\
\mathrm{kg} / \mathrm{m}^{2}\end{array}$ & $25.0(22.1-28.1)$ & $27.4(23.6-31.6)$ & $\begin{array}{l}527 \\
(22 \%)\end{array}$ & $\begin{array}{l}2,524 \\
(3 \%) \\
\end{array}$ \\
\hline Recipient gender, male & $1,566(66 \%)$ & $60,867(60 \%)$ & 0 & 0 \\
\hline Retransplantation & $249(10 \%)$ & $13,308(13 \%)$ & 0 & 0 \\
\hline $\begin{array}{l}\text { Cause of kidney failure } \\
\text { Diabetic kidney disease } \\
\text { Glomerulonephritis } \\
\text { Polycystic kidney disease } \\
\text { Other } \\
\text { Unknown }\end{array}$ & $\begin{array}{l}659(28 \%) \\
623(26 \%) \\
427(18 \%) \\
679(28 \%) \\
0(0.0 \%) \\
\end{array}$ & $\begin{array}{l}25,722(25 \%) \\
20,021(20 \%) \\
7,570(8 \%) \\
47,702(47 \%) \\
459(0.5 \%) \\
\end{array}$ & 0 & 0 \\
\hline $\begin{array}{l}\text { Recipient time in dialysis before } \\
\text { transplantation, median (IQR), } \\
\text { months }\end{array}$ & $22(13-38)$ & $46(23-73)$ & $\begin{array}{l}8 \\
(0.3 \%)\end{array}$ & $\begin{array}{l}10,962 \\
(11 \%)\end{array}$ \\
\hline
\end{tabular}




\begin{tabular}{|c|c|c|c|c|}
\hline Pre-emptive transplantations & $0(0.0 \%)$ & $12,343(12 \%)$ & 0 & $\begin{array}{l}958 \\
(1 \%)\end{array}$ \\
\hline $\begin{array}{l}\text { Number of HLA A and B } \\
\text { mismatches, median (IQR) }\end{array}$ & $2(1-2)$ & $3(2-4)$ & 0 & $\begin{array}{l}738 \\
(0.7 \%)\end{array}$ \\
\hline $\begin{array}{l}\text { Number of HLA DR } \\
\text { mismatches, median (IQR) }\end{array}$ & $1(0-1)$ & $1(1-2)$ & 0 & $\begin{array}{l}739 \\
(0.7 \%) \\
\end{array}$ \\
\hline $\begin{array}{l}\text { Number of HLA mismatches, } \\
\text { median (IQR) }\end{array}$ & $3(2-3)$ & $4(3-5)$ & 0 & $\begin{array}{l}739 \\
(0.7 \%) \\
\end{array}$ \\
\hline Delayed graft function & $849(36 \%)$ & $23,007(23 \%)$ & 0 & $\begin{array}{l}596 \\
(0.6 \%)\end{array}$ \\
\hline Acute rejection & $430(18 \%)$ & NA & 0 & NA \\
\hline Graft survival at 1 year & $95 \%$ & $93 \%$ & $\begin{array}{l}1 \\
(0.0 \%)\end{array}$ & 0 \\
\hline Graft survival at 3 years & $90 \%$ & $85 \%$ & $\begin{array}{l}1 \\
(0.0 \%) \\
(0.0 \%\end{array}$ & 0 \\
\hline Graft survival at 5 years & $82 \%$ & $76 \%$ & $\begin{array}{l}1 \\
(0.0 \%)\end{array}$ & 0 \\
\hline Graft survival at 10 years & $61 \%$ & $50 \%$ & $\begin{array}{l}1 \\
(0.0 \%)\end{array}$ & 0 \\
\hline \multicolumn{5}{|c|}{$\begin{array}{l}\text { Median (IQR) and } n(\%) \text { unless otherwise indicated. BMI= body mass index, HLA= human leukocyte antigen, KDPI= } \\
\text { Kidney Donor Profile Index, NA= not available. } \\
\text { All variables were significantly different between the cohorts ( } p<0.001 \text { for every variable (recipient age } p<0.003 \text { ). } \\
\text { a Percentiles } 0 \text { to } 100 \text {, indicating higher risk of graft failure relative to other kidneys with increasing percentage. } \\
\text { b Organ yield from multiorgan donor, maximum of } 7 \text { (heart, lungs, liver, pancreas, intestine and two kidneys). } \\
\text { In graft survival outcome is defined as death, retransplantation or return to dialysis. }\end{array}$} \\
\hline
\end{tabular}


Table 2. Differences in characteristics of quartiles of kidney transplantations in Finland from June 2004 to December 2017 and the US from January 2008 to August 2008 by quartiles of time from brain death to organ perfusion (procurement delay).

\begin{tabular}{|c|c|c|c|c|c|c|c|c|}
\hline \multirow{2}{*}{$\begin{array}{l}\text { Variable } \\
\begin{array}{l}\text { Quartile, } n \text { of donors, } n \\
\text { of recipients }\end{array}\end{array}$} & \multicolumn{4}{|c|}{$\begin{array}{l}\text { Finland, quartiles of time from brain death to } \\
\text { organ perfusion in organ donors }\end{array}$} & \multicolumn{4}{|c|}{$\begin{array}{l}\text { US, quartiles of time from brain death to organ } \\
\text { perfusion in organ donors }\end{array}$} \\
\hline & $\begin{array}{l}\text { 1st } \\
\text { n: } 321 \\
\text { n: } 596\end{array}$ & $\begin{array}{l}\text { 2nd } \\
\text { n: } 326 \\
\text { n: } 598\end{array}$ & \begin{tabular}{|l|} 
3rd \\
n: 330 \\
n: 597
\end{tabular} & $\begin{array}{l}\text { 4th } \\
\mathrm{n}: 334 \\
\mathrm{n}: 597\end{array}$ & $\begin{array}{l}\text { 1st } \\
\text { n: } 14,689 \\
\text { n: } 25,366\end{array}$ & $\begin{array}{l}\text { 2nd } \\
\mathrm{n}: 14,686 \\
\mathrm{n}: 25,371\end{array}$ & \begin{tabular}{|l|}
$3 \mathrm{rd}$ \\
$\mathrm{n}: 14,711$ \\
$\mathrm{n}: 25,369$
\end{tabular} & $\begin{array}{l}\text { 4th } \\
\mathrm{n}: 14,706 \\
\mathrm{n}: 25,368\end{array}$ \\
\hline $\begin{array}{l}\text { Time from brain death } \\
\text { to organ perfusion, } \\
\text { median (IQR), hours }\end{array}$ & $\begin{array}{l}6.5 \\
(5.8- \\
7.2)\end{array}$ & $\begin{array}{l}8.7(8.2- \\
9.1)\end{array}$ & $\begin{array}{l}10.8 \\
(10.2- \\
11.5)\end{array}$ & $\begin{array}{l}15.1 \\
(13.5- \\
18.0)\end{array}$ & $\begin{array}{l}20.5 \\
(16.1- \\
23.8)\end{array}$ & $\begin{array}{l}30.6 \\
(28.5- \\
32.7)\end{array}$ & $\begin{array}{l}39.6 \\
(37.1- \\
42.6)\end{array}$ & \begin{tabular}{|l|}
57.1 \\
$(50.9-$ \\
$67.1)$
\end{tabular} \\
\hline KDPI, median (IQR), \% & $\begin{array}{l}76(55- \\
89)\end{array}$ & $\begin{array}{l}63(43- \\
81)\end{array}$ & $\begin{array}{l}57(34- \\
79)\end{array}$ & $\begin{array}{l}43(23- \\
62)\end{array}$ & $\begin{array}{l}53(25- \\
77)\end{array}$ & $\begin{array}{l}45(20- \\
69)\end{array}$ & $\begin{array}{l}41(19- \\
66)\end{array}$ & $\begin{array}{l}37(17- \\
62)\end{array}$ \\
\hline $\begin{array}{l}\text { Donor age, median } \\
\text { (IQR), years }\end{array}$ & $\begin{array}{l}61(54- \\
67)\end{array}$ & $\begin{array}{l}56(47- \\
63)\end{array}$ & $\begin{array}{l}53(40- \\
61) \\
\end{array}$ & $\begin{array}{l}48(37- \\
56)\end{array}$ & $\begin{array}{l}43(26- \\
55)\end{array}$ & $\begin{array}{l}37(23- \\
50)\end{array}$ & $\begin{array}{l}35(22- \\
48)\end{array}$ & \begin{tabular}{|l}
$34(22-$ \\
$47)$ \\
\end{tabular} \\
\hline $\begin{array}{l}\text { Donor BMI, median, } \\
\mathrm{kg} / \mathrm{m}^{2}\end{array}$ & $\begin{array}{l}25.7 \\
(23.9- \\
27.8) \\
\end{array}$ & $\begin{array}{l}25.0 \\
(23.3- \\
27.6) \\
\end{array}$ & \begin{tabular}{|l|}
24.7 \\
$(22.9-$ \\
$27.7)$ \\
\end{tabular} & $\begin{array}{l}24.5 \\
(22.9- \\
27.5) \\
\end{array}$ & $\begin{array}{l}26.4 \\
(22.8- \\
30.9) \\
\end{array}$ & $\begin{array}{l}26.0 \\
(22.4- \\
30.6) \\
\end{array}$ & \begin{tabular}{|l|}
26.0 \\
$(22.5-$ \\
$30.4)$ \\
\end{tabular} & \begin{tabular}{|l|}
25.9 \\
$(22.5-$ \\
$30.2)$ \\
\end{tabular} \\
\hline $\begin{array}{l}\text { Donor creatinine, } \\
\text { median, } \mathrm{mg} / \mathrm{dl}\end{array}$ & $\begin{array}{l}0.68 \\
(0.55- \\
0.81)\end{array}$ & $\begin{array}{l}0.67 \\
(0.53- \\
0.80)\end{array}$ & $\begin{array}{l}0.63 \\
(0.50- \\
0.80)\end{array}$ & $\begin{array}{l}0.64 \\
(0.53- \\
0.80)\end{array}$ & $\begin{array}{l}1.00 \\
(0.71- \\
1.36)\end{array}$ & $\begin{array}{l}1.00 \\
(0.70- \\
1.30)\end{array}$ & $\begin{array}{l}1.00 \\
(0.70- \\
1.33)\end{array}$ & \begin{tabular}{|l|}
0.99 \\
$(0.70-$ \\
$1.40)$ \\
\end{tabular} \\
\hline Donor & $\begin{array}{l}125 \\
(39 \%)\end{array}$ & $98(30 \%)$ & $82(25 \%)$ & $72(22 \%)$ & $\begin{array}{l}4,741 \\
(32 \%)\end{array}$ & $\begin{array}{l}3,948 \\
(27 \%) \\
\end{array}$ & \begin{tabular}{|l|}
3,589 \\
$(25 \%)$ \\
\end{tabular} & \begin{tabular}{|l|}
3,203 \\
$(22 \%)$ \\
\end{tabular} \\
\hline $\begin{array}{l}\text { Donor cause of death: } \\
\text { cerebrovascular } \\
\text { accident }\end{array}$ & $\begin{array}{l}236 \\
(74 \%)\end{array}$ & $\begin{array}{l}227 \\
(70 \%)\end{array}$ & \begin{tabular}{|l|}
221 \\
$(67 \%)$
\end{tabular} & $\begin{array}{l}211 \\
(63 \%)\end{array}$ & $\begin{array}{l}5,367 \\
(37 \%)\end{array}$ & $\begin{array}{l}4,675 \\
(32 \%)\end{array}$ & $\begin{array}{l}4,189 \\
(29 \%)\end{array}$ & $\begin{array}{l}3,909 \\
(27 \%)\end{array}$ \\
\hline Donor resuscitated & $\begin{array}{l}53 \\
(17 \%)\end{array}$ & $60(18 \%)$ & $56(17 \%)$ & $60(18 \%)$ & $\begin{array}{l}1,149 \\
(8 \%)\end{array}$ & & $\begin{array}{l}1,122 \\
(8 \%)\end{array}$ & $\begin{array}{l}1,014 \\
(7 \%)\end{array}$ \\
\hline Donor diabetes & $23(7 \%)$ & $15(5 \%)$ & $6(2 \%)$ & $13(4 \%)$ & $\begin{array}{l}1,292 \\
(9 \%)\end{array}$ & $\begin{array}{l}1,028 \\
(7 \%) \\
\end{array}$ & $903(6 \%)$ & $808(6 \%)$ \\
\hline $\begin{array}{l}\text { Donor organ yielda, } \\
\text { median }\end{array}$ & $2(2-2)$ & $3(2-3)$ & $3(2-3)$ & $3(2-4)$ & $3(2-4)$ & $3(3-4)$ & $4(3-5)$ & $4(3-5)$ \\
\hline $\begin{array}{l}\text { Cold ischemia time, } \\
\text { median, hours }\end{array}$ & $\begin{array}{l}20.9 \\
(18.1- \\
23.6)\end{array}$ & \begin{tabular}{|l|}
20.6 \\
$(18.0-$ \\
$23.8)$ \\
\end{tabular} & \begin{tabular}{|l|}
20.3 \\
$(16.9-$ \\
$23.3)$ \\
\end{tabular} & \begin{tabular}{|l|}
19.4 \\
$(14.5-$ \\
$22.9)$ \\
\end{tabular} & $\begin{array}{l}16.3 \\
(10.8- \\
23.0)\end{array}$ & $\begin{array}{l}16.0 \\
(11.1- \\
21.1)\end{array}$ & $\begin{array}{l}14.1(9.7- \\
21.2)\end{array}$ & \begin{tabular}{|l|}
15.5 \\
$(10.2-$ \\
$21.5)$ \\
\end{tabular} \\
\hline $\begin{array}{l}\text { Recipient age, median, } \\
\text { years }\end{array}$ & $\begin{array}{l}57(48- \\
65)\end{array}$ & $\begin{array}{l}54(42- \\
62)\end{array}$ & $\begin{array}{l}51(40- \\
60)\end{array}$ & $\begin{array}{l}48(37- \\
58)\end{array}$ & $\begin{array}{l}56(45- \\
64)\end{array}$ & $\begin{array}{l}54(42- \\
63)\end{array}$ & $\begin{array}{l}53(41- \\
62)\end{array}$ & \begin{tabular}{|l}
$52(40-$ \\
$62)$
\end{tabular} \\
\hline Recipient diabetes & $\begin{array}{l}147 \\
(25 \%)\end{array}$ & $\begin{array}{l}165 \\
(28 \%) \\
\end{array}$ & \begin{tabular}{|l|}
162 \\
$(27 \%)$ \\
\end{tabular} & $\begin{array}{l}185 \\
(31 \%) \\
\end{array}$ & $\begin{array}{l}9,232 \\
(36 \%)\end{array}$ & $\begin{array}{l}8,594 \\
(34 \%)\end{array}$ & \begin{tabular}{|l|}
8315 \\
$(33 \%)$ \\
\end{tabular} & \begin{tabular}{|l|}
8,167 \\
$(32 \%)$ \\
\end{tabular} \\
\hline HLA MM total, median & $3(2-3)$ & $3(2-3)$ & $3(2-3)$ & $3(2-3)$ & $4(3-5)$ & $4(3-5)$ & $4(3-5)$ & $4(3-5)$ \\
\hline $\begin{array}{l}\text { Previous kidney } \\
\text { transplant }\end{array}$ & $\begin{array}{l}65 \\
(11 \%)\end{array}$ & $58(10 \%)$ & $64(11 \%)$ & $62(10 \%)$ & $\begin{array}{l}2,960 \\
(12 \%)\end{array}$ & $\begin{array}{l}3,204 \\
(13 \%)\end{array}$ & \begin{tabular}{|l|}
3,481 \\
$(14 \%)$
\end{tabular} & \begin{tabular}{|l|}
3,663 \\
$(14 \%)$
\end{tabular} \\
\hline Donor african-american & NA & $\mathrm{NA}$ & NA & $\mathrm{NA}$ & $\begin{array}{l}1,987 \\
(14 \%)\end{array}$ & $\begin{array}{l}2,405 \\
(16 \%)\end{array}$ & \begin{tabular}{|l|}
2,634 \\
$(18 \%)$
\end{tabular} & \begin{tabular}{|l|}
2,655 \\
$(18 \%)$
\end{tabular} \\
\hline $\begin{array}{l}\text { Recipient african- } \\
\text { american }\end{array}$ & NA & NA & NA & NA & $\begin{array}{l}8,737 \\
(34 \%)\end{array}$ & $\begin{array}{l}8,499 \\
(34 \%)\end{array}$ & \begin{tabular}{|l|}
8,421 \\
$(33 \%)$
\end{tabular} & \begin{tabular}{|l|}
7,545 \\
$(30 \%)$
\end{tabular} \\
\hline $\begin{array}{l}\text { Recipient BMI, median, } \\
\mathrm{kg} / \mathrm{m}^{2}\end{array}$ & $\begin{array}{l}25.5 \\
(22.7- \\
28.5)\end{array}$ & \begin{tabular}{|l|}
25.2 \\
$(22.1-$ \\
$28.1)$ \\
\end{tabular} & \begin{tabular}{|l|}
24.8 \\
$(22.3-$ \\
$28.0)$ \\
\end{tabular} & \begin{tabular}{|l|}
24.3 \\
$(21.6-$ \\
$28.1)$ \\
\end{tabular} & $\begin{array}{l}27.6 \\
(23.9- \\
31.7)\end{array}$ & $\begin{array}{l}27.5 \\
(23.6- \\
31.7)\end{array}$ & \begin{tabular}{|l|}
27.3 \\
$(23.5-$ \\
$31.6)$ \\
\end{tabular} & \begin{tabular}{|l|}
27.1 \\
$(23.3-$ \\
$31.3)$ \\
\end{tabular} \\
\hline $\begin{array}{l}\text { Recipient time in } \\
\text { dialysis, months, } \\
\text { median (IQR) }\end{array}$ & $\begin{array}{l}23(15- \\
38)\end{array}$ & $\begin{array}{l}23(14- \\
38)\end{array}$ & $\begin{array}{l}22(12- \\
38)\end{array}$ & $\begin{array}{l}19(12- \\
36)\end{array}$ & $\begin{array}{l}43(23- \\
67)\end{array}$ & $\begin{array}{l}43(23- \\
69)\end{array}$ & $\begin{array}{l}46(23- \\
74)\end{array}$ & $\begin{array}{l}51(25- \\
83)\end{array}$ \\
\hline \multicolumn{9}{|c|}{$\begin{array}{l}\text { BMI= body-mass index, HLA MM= human leukocyte antigen mismatches, } \mathrm{KDPI}=\text { Kidney Donor Profile Index, NA= not } \\
\text { available, Time from brain death to organ perfusion= time from declaration of brain death to in situ organ cold perfusion. } \\
\mathrm{KDPI} \text { is calculated from donor age, height, weight, history of diabetes and hypertension, cause of death, creatinine and } \\
\text { race. } \\
\text { a Organ yield from multiorgan donor, maximum of } 7 \text { (heart, lungs, liver, pancreas, intestine and two kidneys) }\end{array}$} \\
\hline
\end{tabular}


Table 3. Outcomes of kidney transplantations in Finland from June 2004 to December 2017 and the US from January 2008 to August 2008 by quartiles of time from brain death to organ perfusion (procurement delay). Graft survival is defined as alive with a functioning graft.

\begin{tabular}{|c|c|c|c|c|c|c|c|c|}
\hline \multirow{2}{*}{$\begin{array}{l}\text { Variable } \\
\text { Quartile, n of } \\
\text { transplantations }\end{array}$} & \multicolumn{4}{|c|}{$\begin{array}{c}\text { Finland, quartiles of time from brain death to } \\
\text { organ perfusion in organ donors }\end{array}$} & \multicolumn{4}{|c|}{$\begin{array}{l}\text { US, quartiles of time from brain death to } \\
\text { organ perfusion in organ donors }\end{array}$} \\
\hline & $\begin{array}{l}\text { 1st } \\
\mathrm{n}: 596\end{array}$ & $\begin{array}{l}\text { 2nd } \\
\text { n: } 598\end{array}$ & $\begin{array}{l}3 r d \\
\text { n: } 597\end{array}$ & $\begin{array}{l}\text { 4th } \\
\mathrm{n}: 597\end{array}$ & $\begin{array}{l}1 \mathrm{st} \\
\mathrm{n}: \\
14,635\end{array}$ & $\begin{array}{l}\text { 2nd } \\
n: \\
14,828\end{array}$ & $\begin{array}{l}3 \mathrm{rd} \\
\mathrm{n}: \\
14,838\end{array}$ & $\begin{array}{l}\text { 4th } \\
\text { n: } 14,641\end{array}$ \\
\hline $\begin{array}{l}\text { Delayed graft } \\
\text { function }\end{array}$ & $\begin{array}{l}233 \\
(39 \%)\end{array}$ & $\begin{array}{l}222 \\
(37 \%)\end{array}$ & $\begin{array}{l}204 \\
(34 \%)\end{array}$ & $\begin{array}{l}190 \\
(32 \%)\end{array}$ & $\begin{array}{l}6059 \\
(24 \%)\end{array}$ & $\begin{array}{l}5614 \\
(22 \%)\end{array}$ & $\begin{array}{l}5458 \\
(22 \%)\end{array}$ & $\begin{array}{l}5944 \\
(24 \%)\end{array}$ \\
\hline Acute rejection & $\begin{array}{l}115 \\
(19 \%)\end{array}$ & $\begin{array}{l}107 \\
(18 \%)\end{array}$ & $\begin{array}{l}106 \\
(18 \%)\end{array}$ & $\begin{array}{l}102 \\
(17 \%)\end{array}$ & NA & NA & NA & NA \\
\hline $\begin{array}{l}\text { 1-year graft } \\
\text { survival }\end{array}$ & $93 \%$ & $96 \%$ & $94 \%$ & $95 \%$ & $92 \%$ & $93 \%$ & $94 \%$ & $94 \%$ \\
\hline $\begin{array}{l}\text { 5-year graft } \\
\text { survival }\end{array}$ & $75 \%$ & $85 \%$ & $84 \%$ & $84 \%$ & $74 \%$ & $76 \%$ & $77 \%$ & $78 \%$ \\
\hline $\begin{array}{l}\text { 10-year graft } \\
\text { survival }\end{array}$ & $54 \%$ & $63 \%$ & $62 \%$ & $69 \%$ & $47 \%$ & $50 \%$ & $53 \%$ & $51 \%$ \\
\hline $\begin{array}{l}\text { Follow-up, } \\
\text { median (IQR), } \\
\text { years }\end{array}$ & $\begin{array}{l}4.1(2.0- \\
8.0)\end{array}$ & $\begin{array}{l}5.2 \\
(2.7- \\
9.0) \\
\end{array}$ & $\begin{array}{l}5.3(2.3- \\
8.8)\end{array}$ & $\begin{array}{l}4.1(1.7- \\
7.0)\end{array}$ & $\begin{array}{l}4.2 \\
(2.0- \\
6.9) \\
\end{array}$ & $\begin{array}{l}3.8 \\
(1.7- \\
6.0) \\
\end{array}$ & $\begin{array}{l}2.9 \\
(1.0- \\
5.0) \\
\end{array}$ & $\begin{array}{l}1.9(0.7- \\
3.8)\end{array}$ \\
\hline $\begin{array}{l}\text { Graft survival, } \\
\text { median, years }\end{array}$ & 10.9 & 13.0 & $>13.5^{\mathrm{a}}$ & 13.5 & 9.7 & 10.0 & 10.3 & 10.1 \\
\hline
\end{tabular}




\section{FIGURES}

Figure 1. Distribution of time from declaration of brain death to cold perfusion in

Finnish organ donors from June 2004 to December 2017 and SRTR organ donors from January 2008 to August 2018.

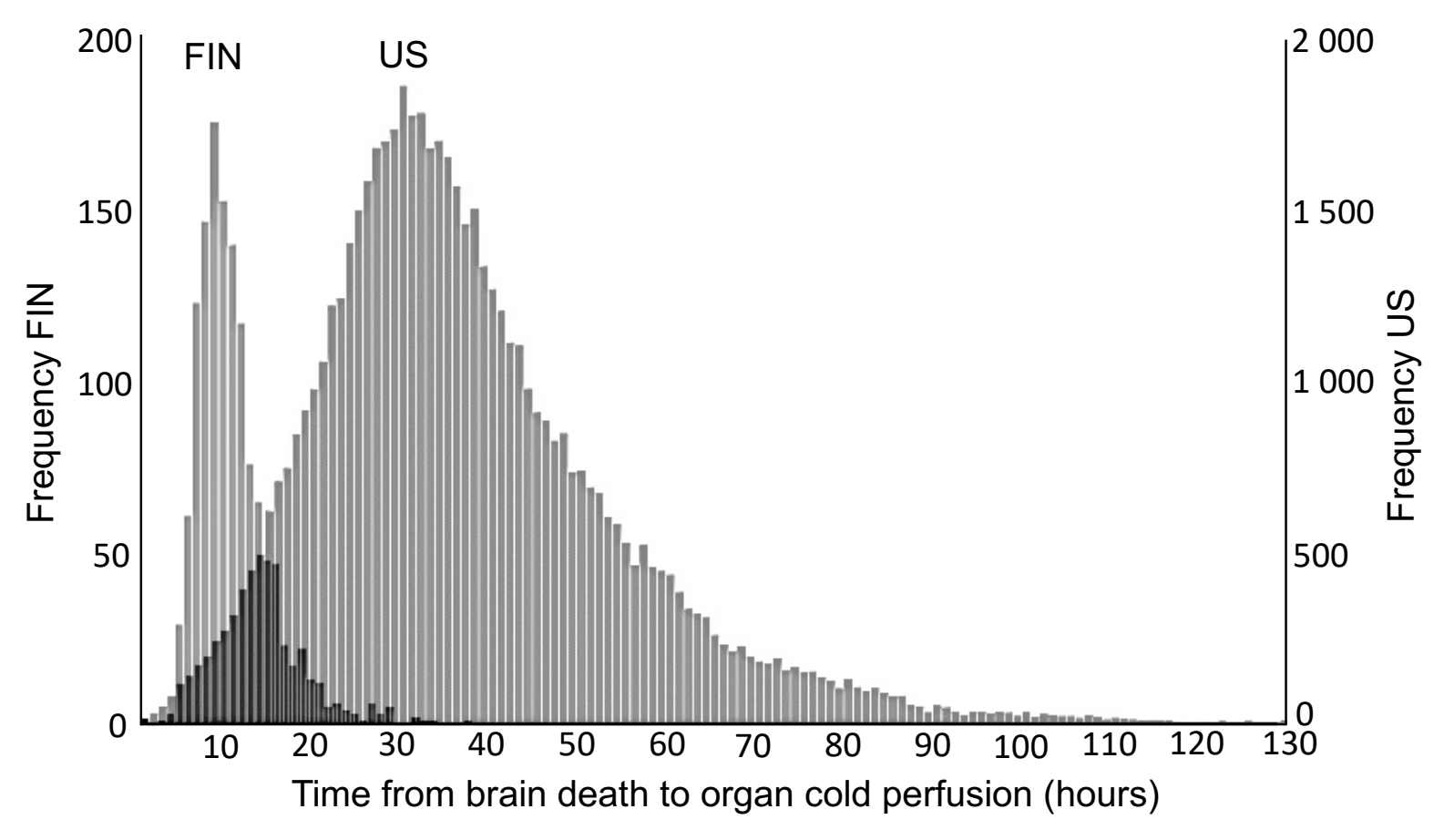


Figure 2. The estimated probability (black line) of delayed graft function as a function of procurement delay when assessed using unadjusted $(A, B)$ and multivariable (C) logistic regression model with restricted cubic spline function. Gray area corresponds to $95 \%$ confidence band. A) Finnish cohort: $p=0.67$ for non-linear association. B) US cohort: $p<0.001$ for non-linear association. C) US cohort: $p<0.001$ for non-linear association. Predicted values were calculated by setting confounder values to their median (KDPI=45, recipient age $=53$ years, dialysis vintage $=45.57$ months) or the most frequent category (no diabetes).
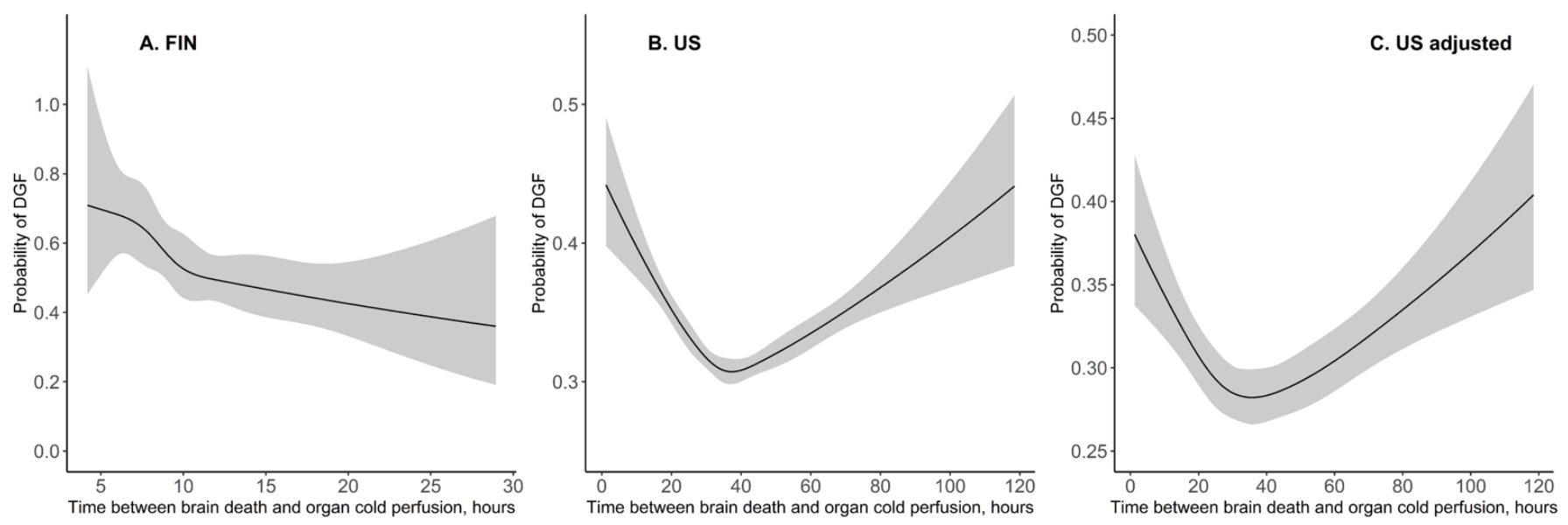
Figure 3. Graft survival of kidney transplants in Finland from June 2004 to December

\section{7 and the US from January 2008 to August 2018 by quartiles of time from brain}

death to cold perfusion (procurement delay in hours). Outcome is defined as death,

return to dialysis, or retransplantation.

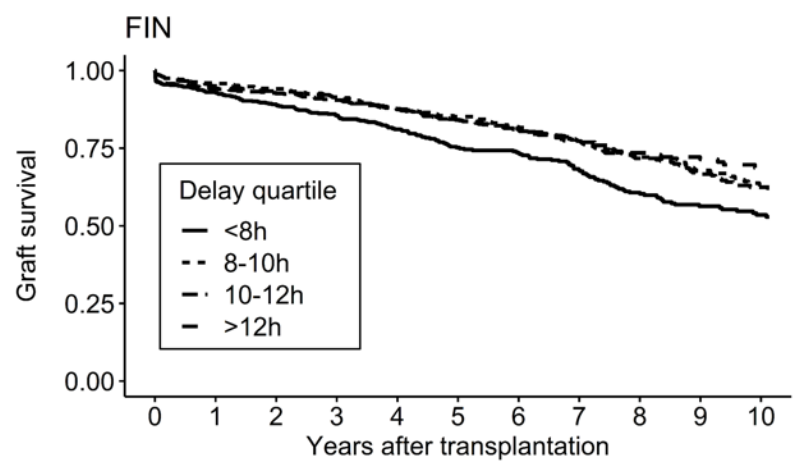

Patients at risk

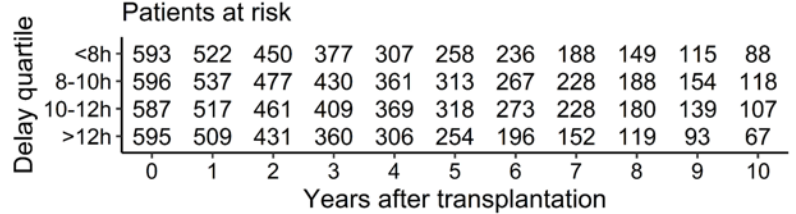

Cumulative number of events

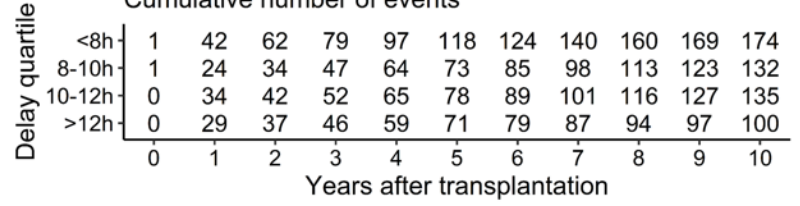

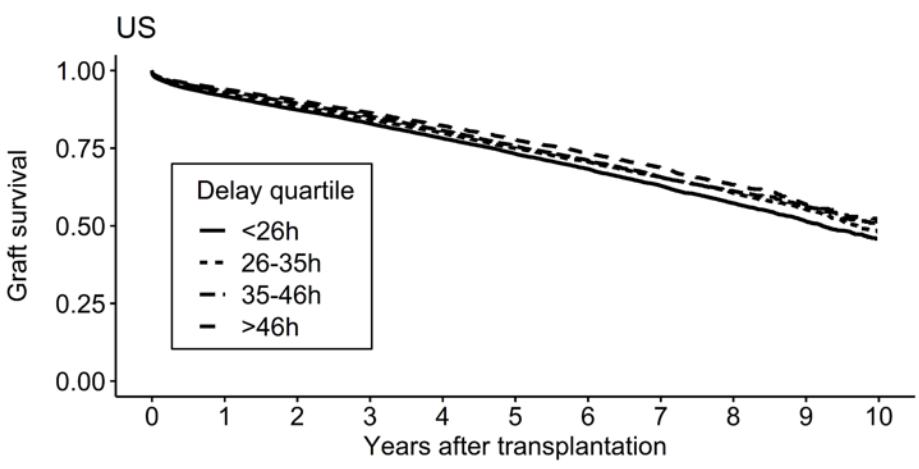

Patients at risk

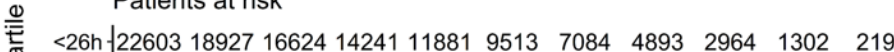

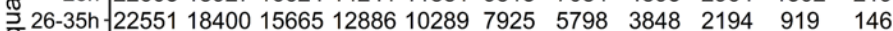

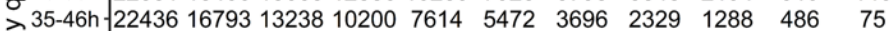
$\frac{\pi}{0}>46 \mathrm{~h}\left[\begin{array}{lllllllllll}22156 & 14304 & 10032 & 6919 & 4674 & 3101 & 2003 & 1229 & 637 & 237 & 42 \\ \hline\end{array}\right.$

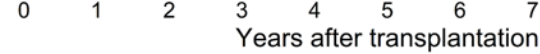

Cumulative number of events

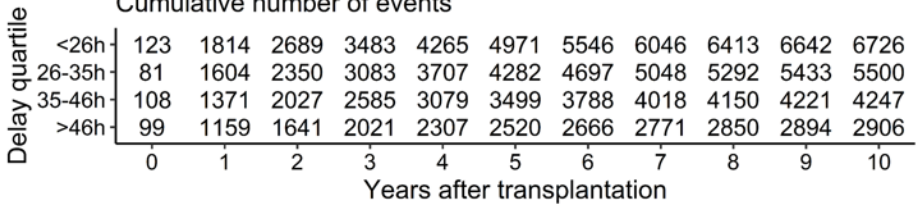


Figure 4. The estimated relative hazard (black line) of graft failure or death as a function of procurement delay when assessed using unadjusted Cox regression model with restricted cubic spline function. Grey area corresponds to $95 \%$ confidence band, $p=0.005$ for non-linear association in Finnish cohort and $p=0.11$ for non-linear association in the US cohort.
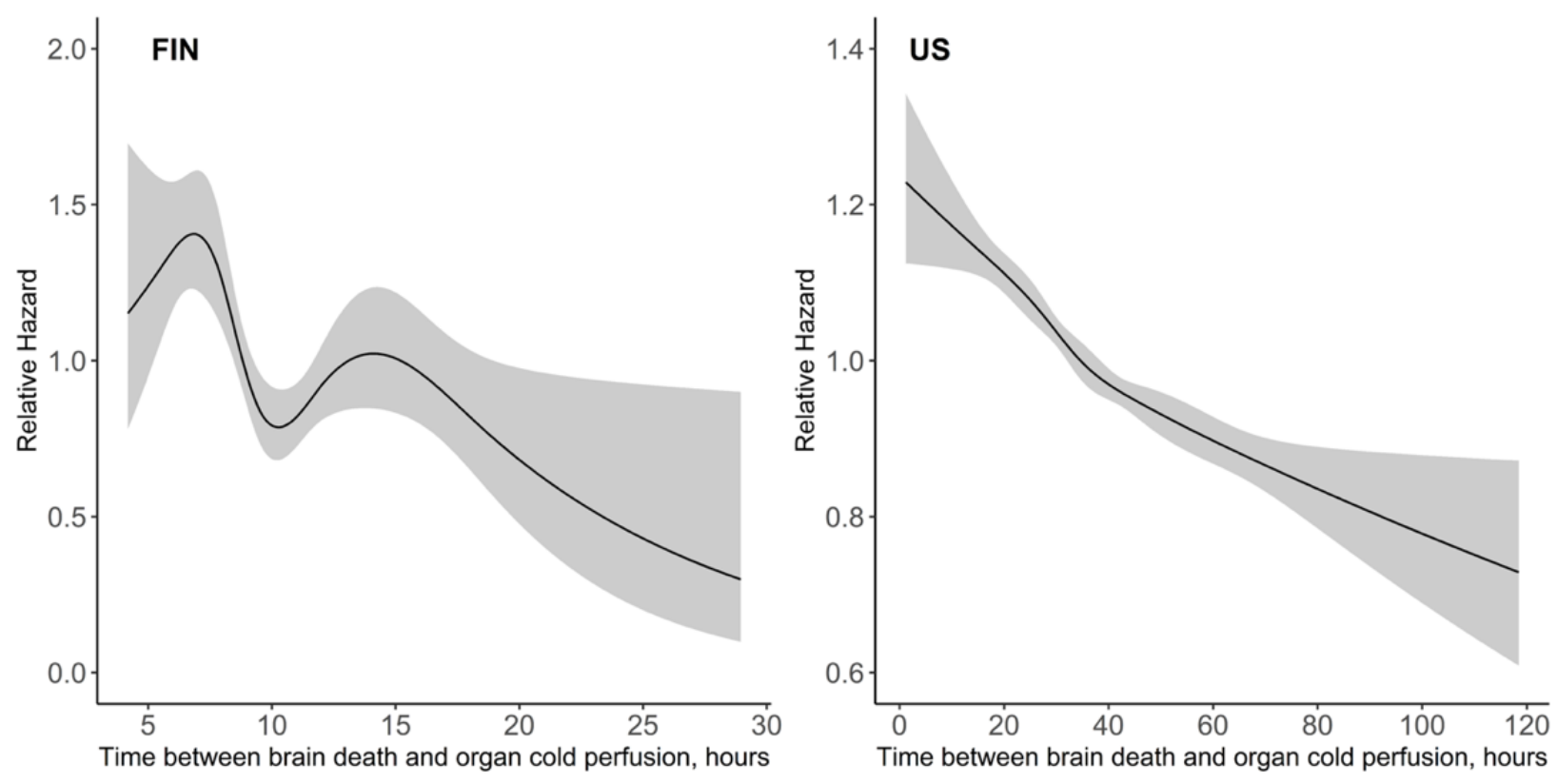


\section{SUPPLEMENTAL MATERIAL}

Directed acyclic graph (DAG)

Figure 1: Graphical presentation of confounding and mediators in our study

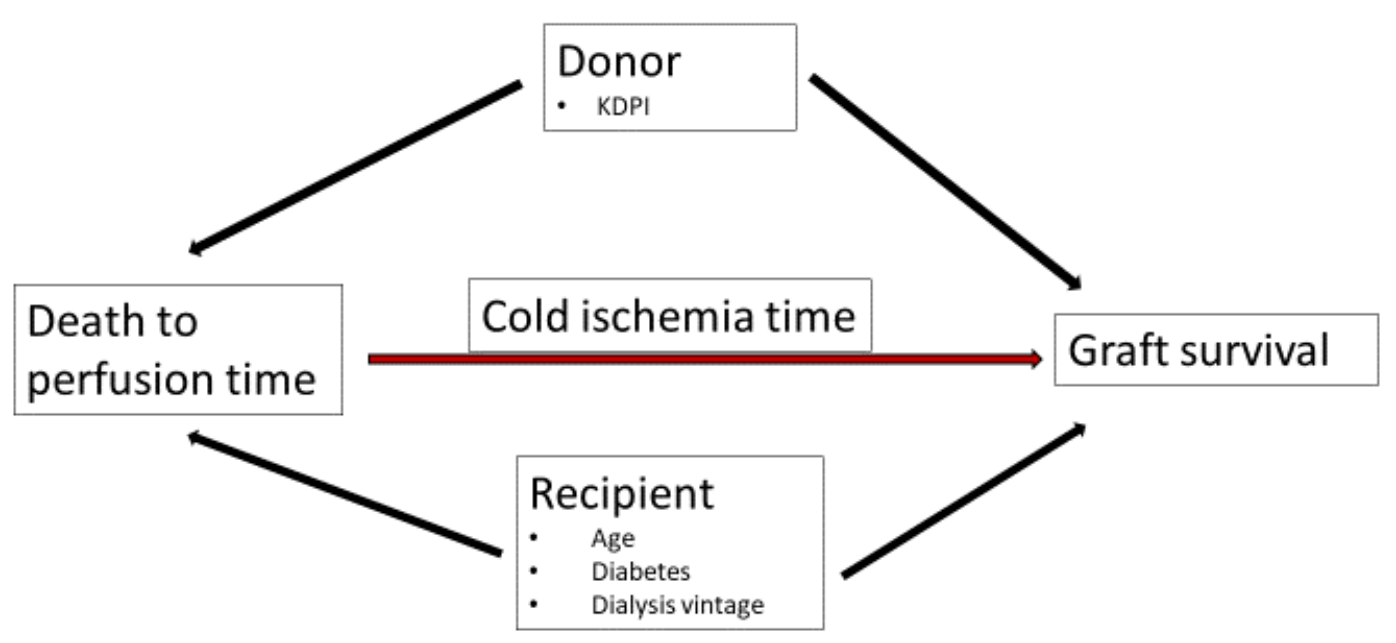


Sensitivity analyses

Table 1. US cohort, time dependent hazard ratio

In the US cohort, the association between procurement delay and hazard attenuated over time. We accounted for non-proportionality by splitting the follow-up time and assessing time-varying HRs of DTPT by three follow-up periods $(0-1.5,1.5-4,>4$ years) without and with adjustment for confounders. Time-dependent variation of the confounder's regression coefficients was accounted for by introducing to the model interactions between confounders and follow-up time.

Univariate (FUT = follow-up time)

FUT HR $\quad 95 \% \mathrm{Cl} \quad \mathrm{p}$-val

$0-1.5 y \quad 0.9930 \quad 0.9914-0.9946 .<2 e-16$

$\begin{array}{llll}1.5-4 y & 0.9968 & 0.9951-0.9986 & 0.000386\end{array}$

$\begin{array}{llll}>4 \mathrm{y} & 0.9973 \quad 0.9954-0.9993 \quad 0.008500\end{array}$

Multivariable

FUT HR $\quad 95 \% \mathrm{Cl} \quad \mathrm{p}$-val

0-1.5y $0.9951 \quad 0.9936-0.9967 \quad 8.01 \mathrm{e}-10$

$\begin{array}{llll}1.5-4 y & 0.9982 & 0.9965-1.0000 & 0.04759\end{array}$

$\begin{array}{llll}>4 y & 0.9993 & 0.9974-1.0013 & 0.50743\end{array}$ 
Cox regression model by KAS

Before KAS (55401 transplantations, 16686 events): $p=0.100$ for non-linearity in the univariate model (Figure 1), adjusted $\mathrm{HR}=0.948(95 \% \mathrm{Cl} 0.931-0.965, \mathrm{p}<0.0001)$

US cohort, before KAS

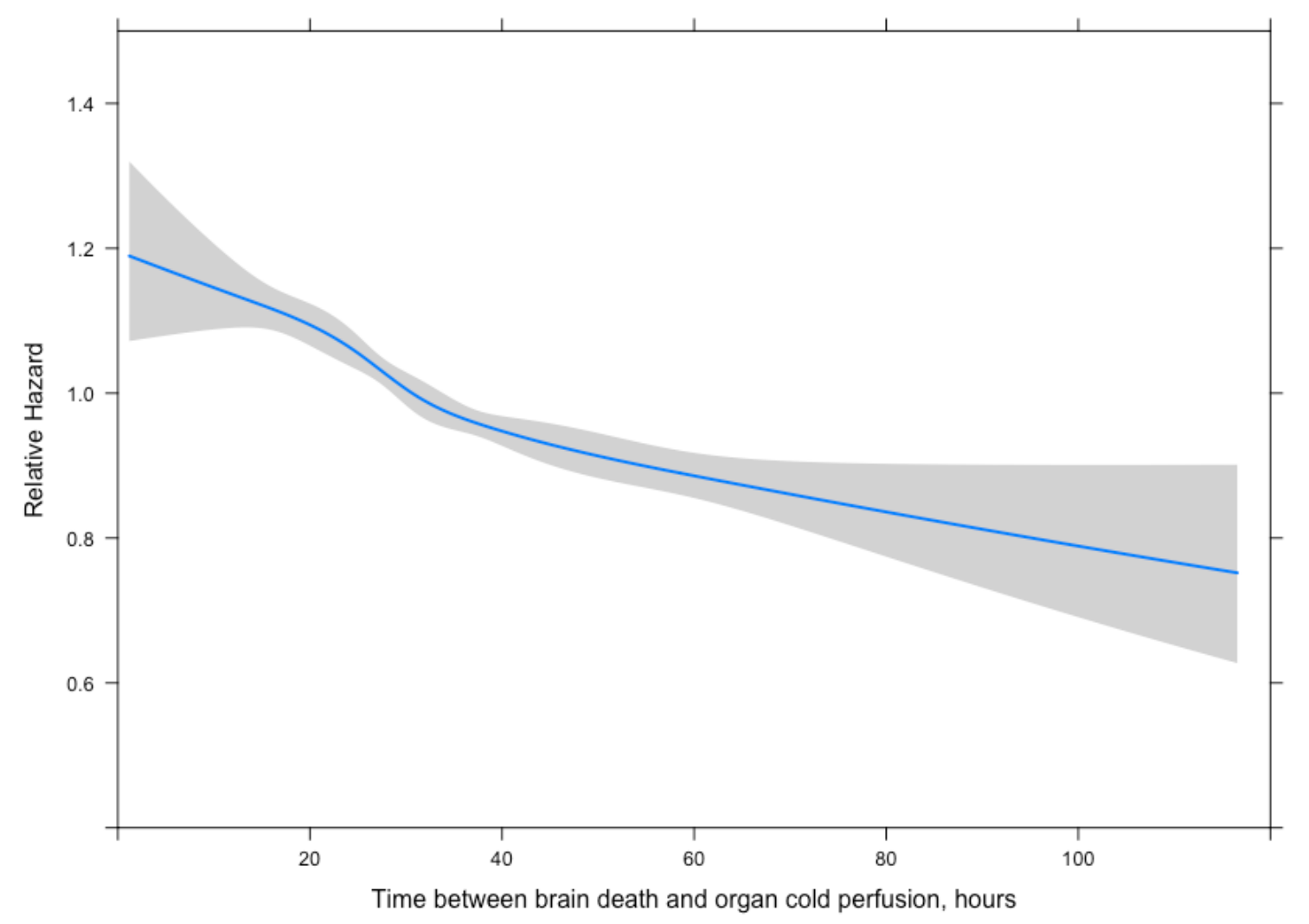

Figure 2. The relative hazard predicted from the univariate model with a restricted cubic spline. Sensitivity analysis before KAS, US cohort. 
After KAS (34413 transplantations, 2737 events): $p=0.958$ for non-linearity in the univariate model (Figure 2), adjusted HR=0.949 (95\% Cl 0.904-0.997, $p=0.037$ ) US cohort, post KAS

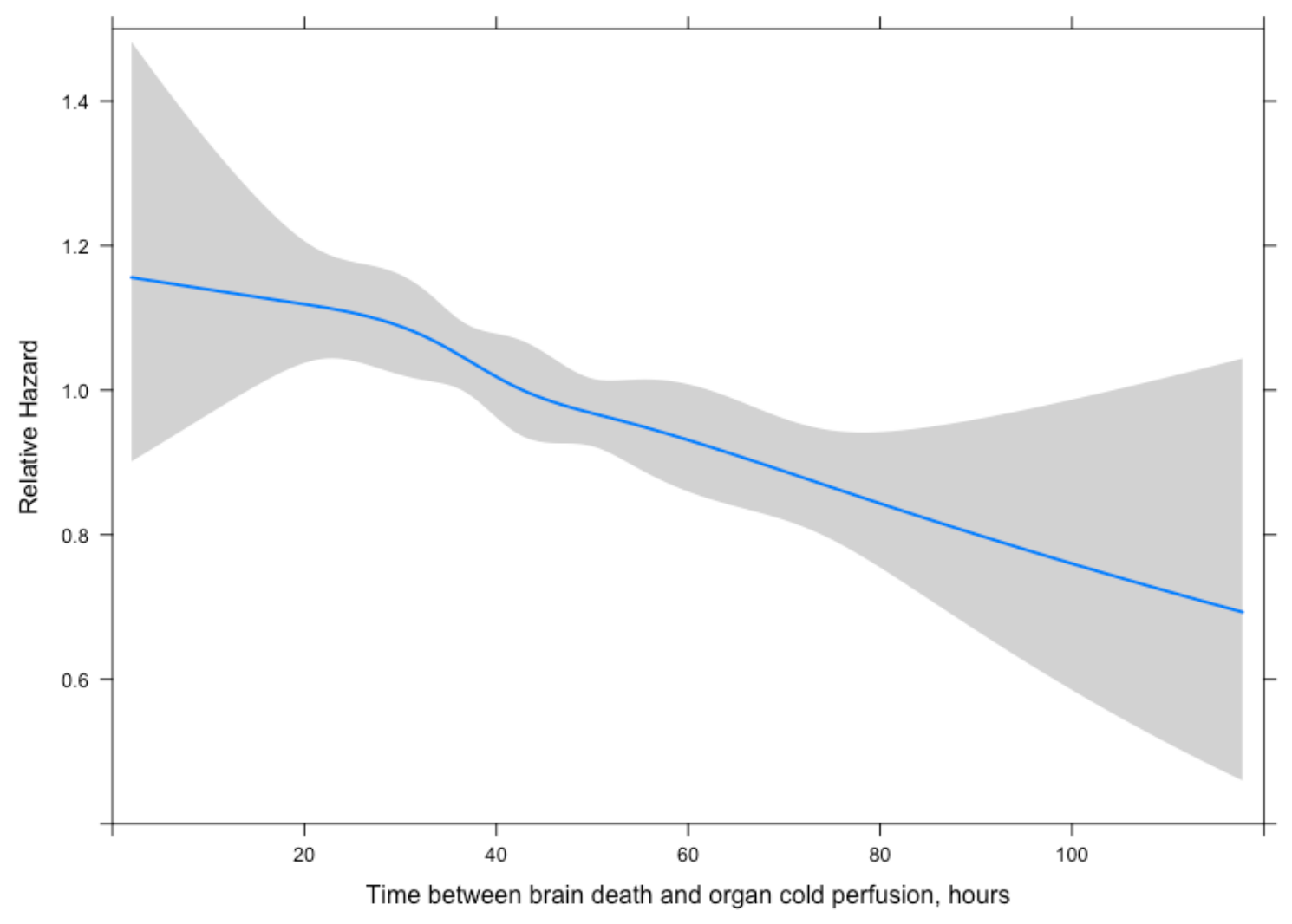

Figure 3. The relative hazard predicted from the univariate model with a restricted cubic spline. Sensitivity analysis after KAS, US cohort. 
Cox regression model by organ yield

Procurement of kidney(s) only (9204 transplantations, 2410 events): $p=0.030$ for non-linearity in the univariate model (Figure 3 ) and $p=0.429$ in multivariable model; adjusted $\mathrm{HR}=0.946(95 \% \mathrm{Cl} 0.898-0.997,0.040)$

US cohort, procurement of kidney(s) only

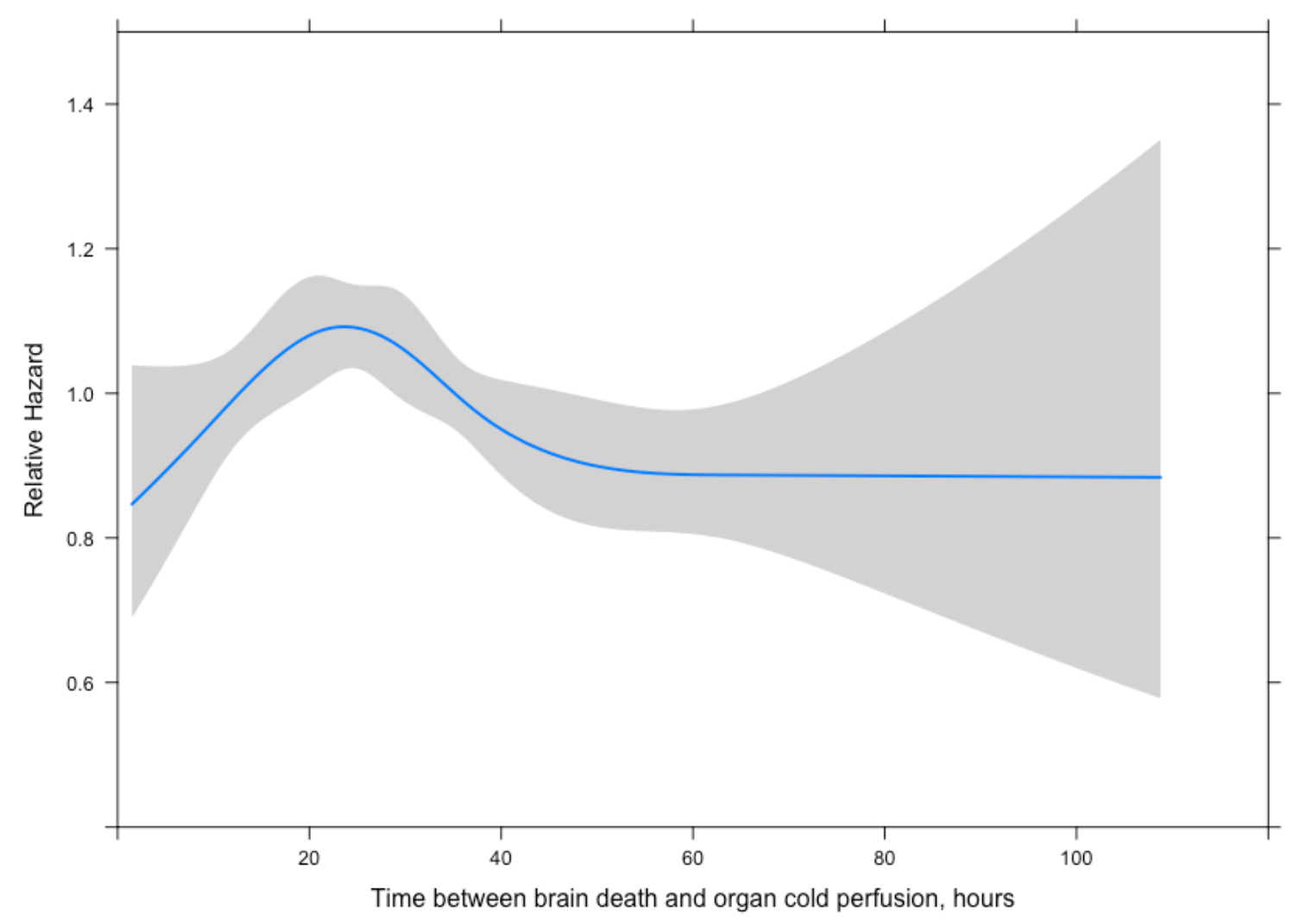

Figure 4. The relative hazard predicted from the univariate model with a restricted cubic spline. Sensitivity analysis of organ yield, kidneys only, US cohort. 
Procurement of kidney(s) and one other organ (34996 transplantations, 8669 events): $p=0.576$ for non-linearity in the univariate model (Figure 4) and $p=0.897$ in multivariable model; adjusted $\mathrm{HR}=0.933(95 \% \mathrm{Cl} 0.907-0.960, \mathrm{p}<0.0001)$

US cohort, procurement of kidney(s) and one other organ

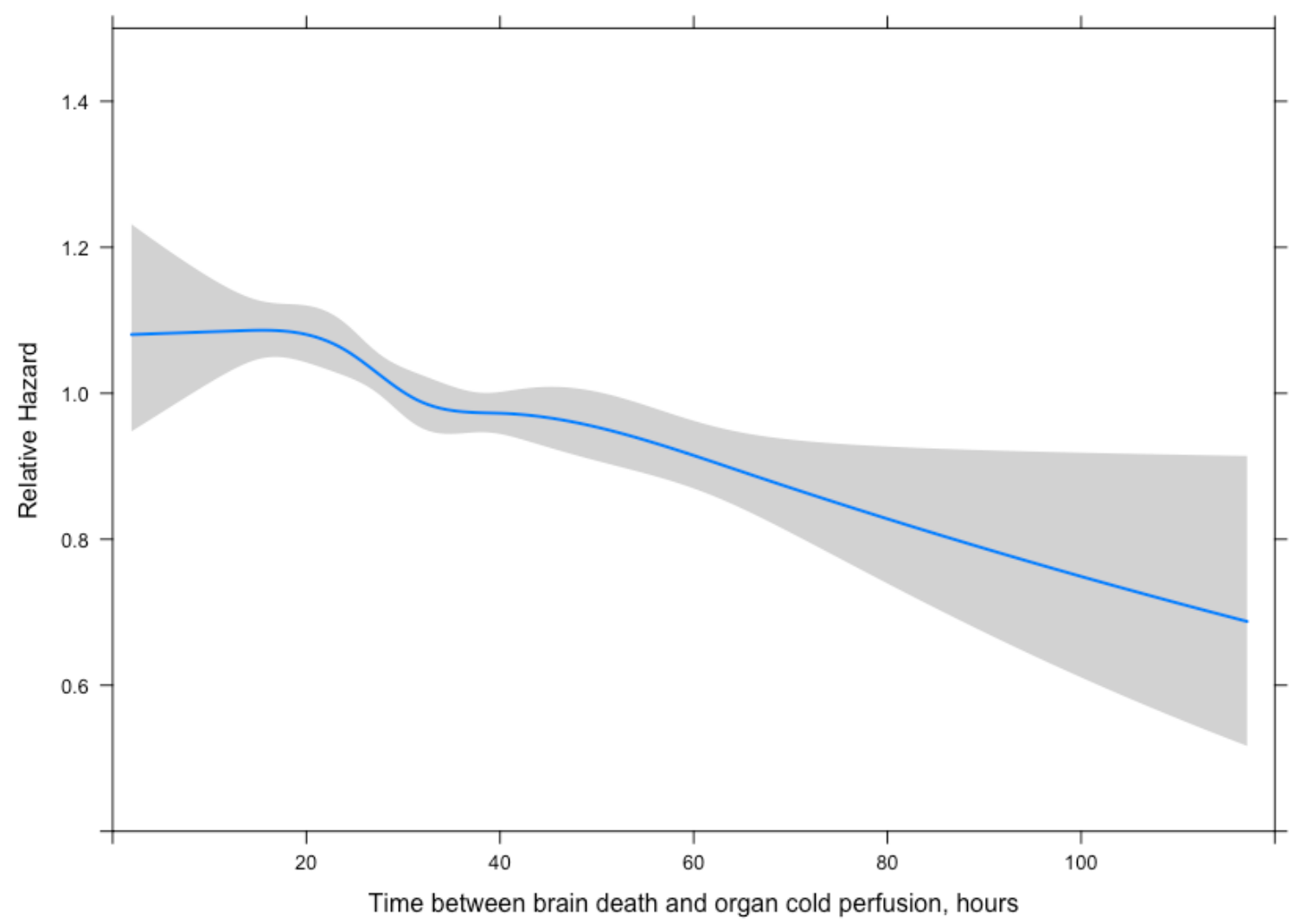

Figure 5. The relative hazard predicted from the univariate model with a restricted cubic spline. Sensitivity analysis of organ yield, kidneys and one other organ, US cohort. 
Procurement of kidney(s) and two other organs (25892 transplantations, 4911 events): $p=0.083$ for non-linearity in the univariate model (Figure 5 ) and $p=p=0.109$ in multivariable model; adjusted $\mathrm{HR}=0.935(95 \% \mathrm{Cl} 0.900-0.971, \mathrm{p}=0.0005)$

US cohort, procurement of kidney(s) and two other organs

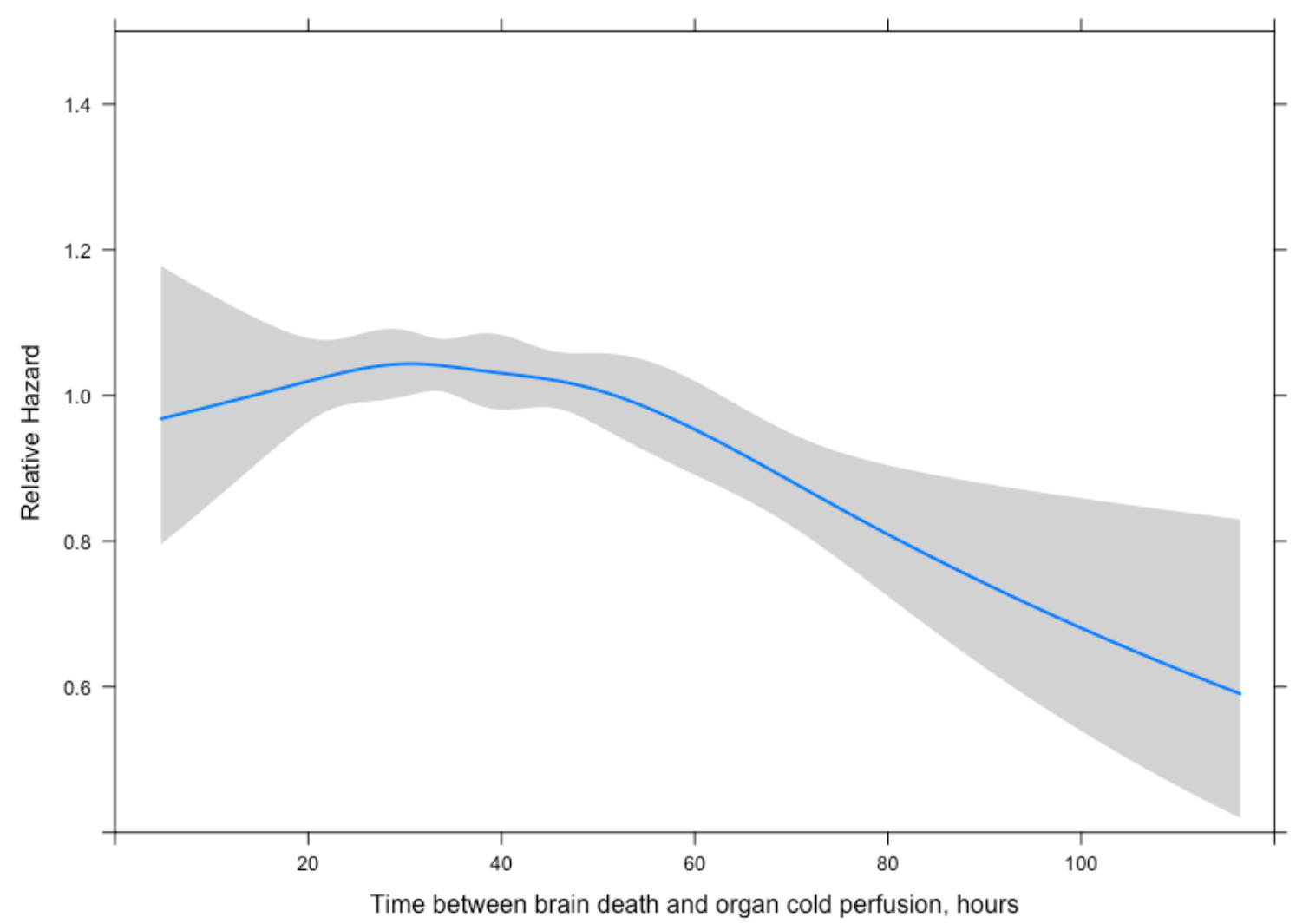

Figure 6. The relative hazard predicted from the univariate model with a restricted cubic spline. Sensitivity analysis of organ yield, kidneys and two other organs, US cohort. 
Procurement of kidney(s) and more than two other organs (19722 transplantations, 3433 events): $p=0.576$ for non-linearity in the univariate model (Figure 6) and $p=0.897$ in multivariable model; adjusted $\mathrm{HR}=0.958(95 \% \mathrm{Cl} 0.914$ 1.005, $p=0.0770$ )

US cohort, procurement of kidney(s) and more than two other organs

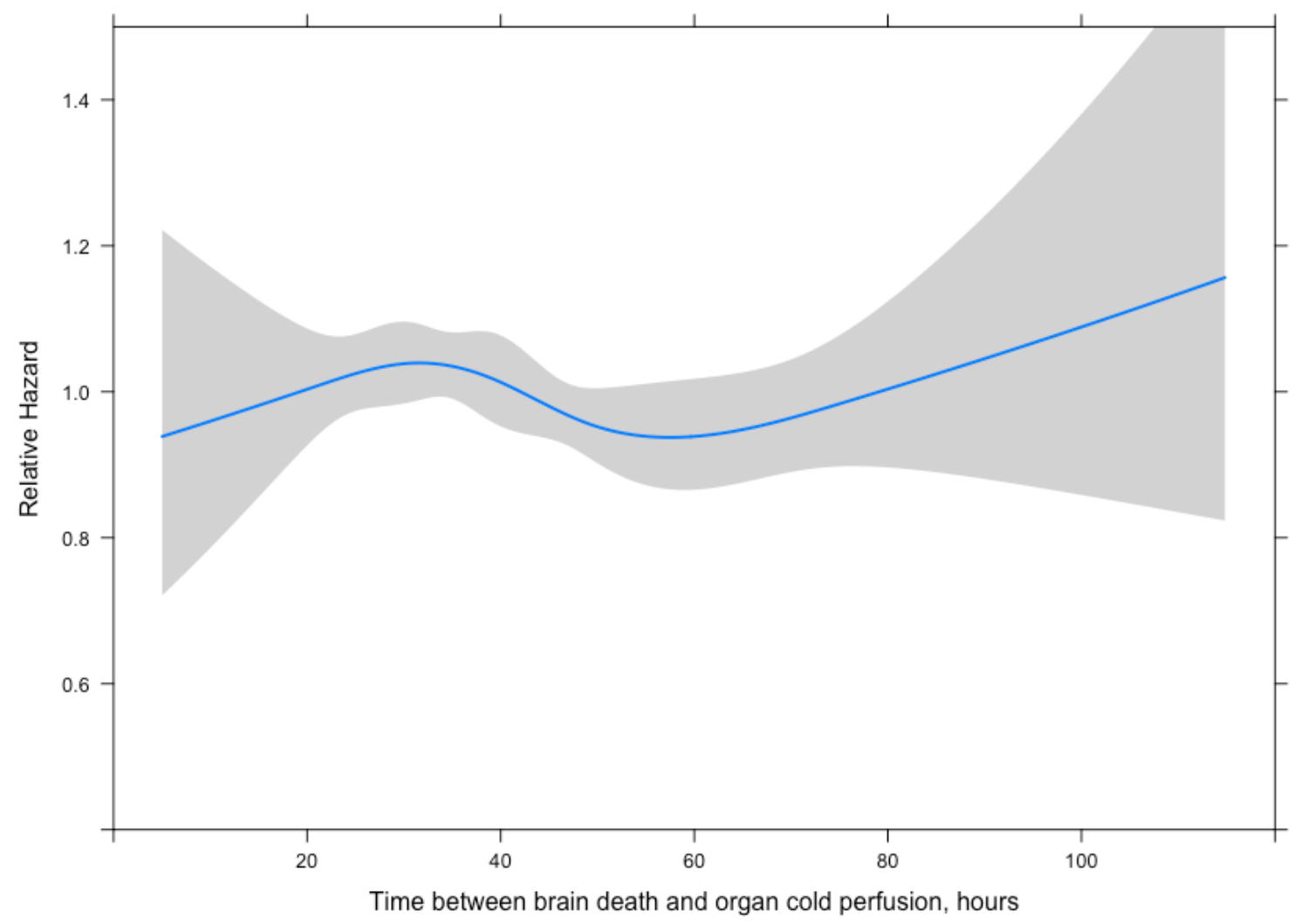

Figure 7. The relative hazard predicted from the univariate model with a restricted cubic spline. Sensitivity analysis of organ yield, kidneys and more than two other organs, US cohort. 
Cox regression model by cold ischemia time (CIT)

CIT < 12h (29378 transplantations, 2410 events): $p=0.152$ for non-linearity in the univariate model (Figure 7) and $p=0.035$ in multivariable model (Figure 8); adjusted $\mathrm{HR}=0.905(95 \% \mathrm{Cl} 0.873-0.938, \mathrm{p}<0.0001)$

US cohort, cold ischemia time $<12$ hours

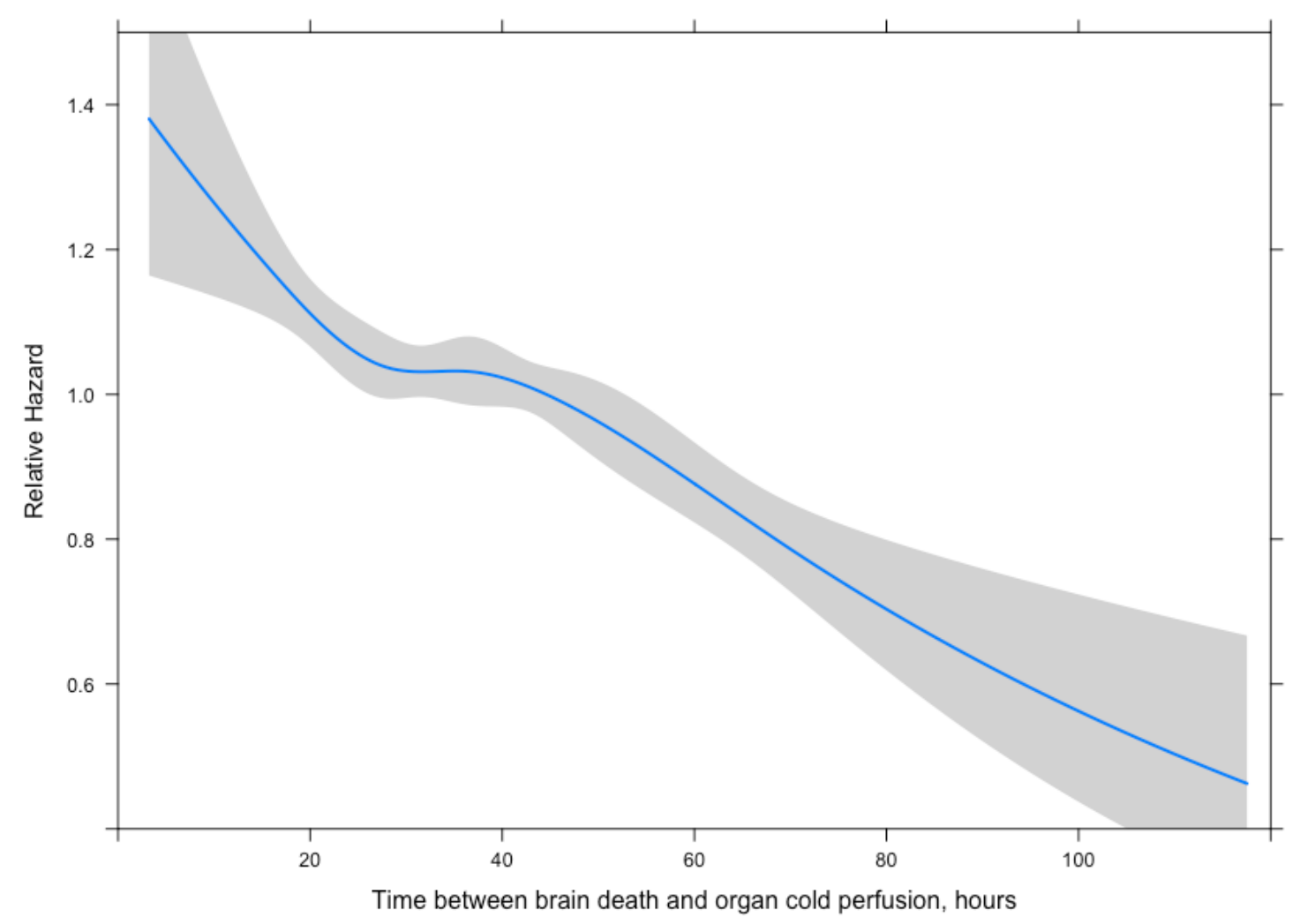

Figure 8. The relative hazard predicted from the univariate model with a restricted cubic spline. Sensitivity analysis of cold ischemia time $<12 \mathrm{~h}$, US cohort. 
US cohort, cold ischemia time $<12$ hours

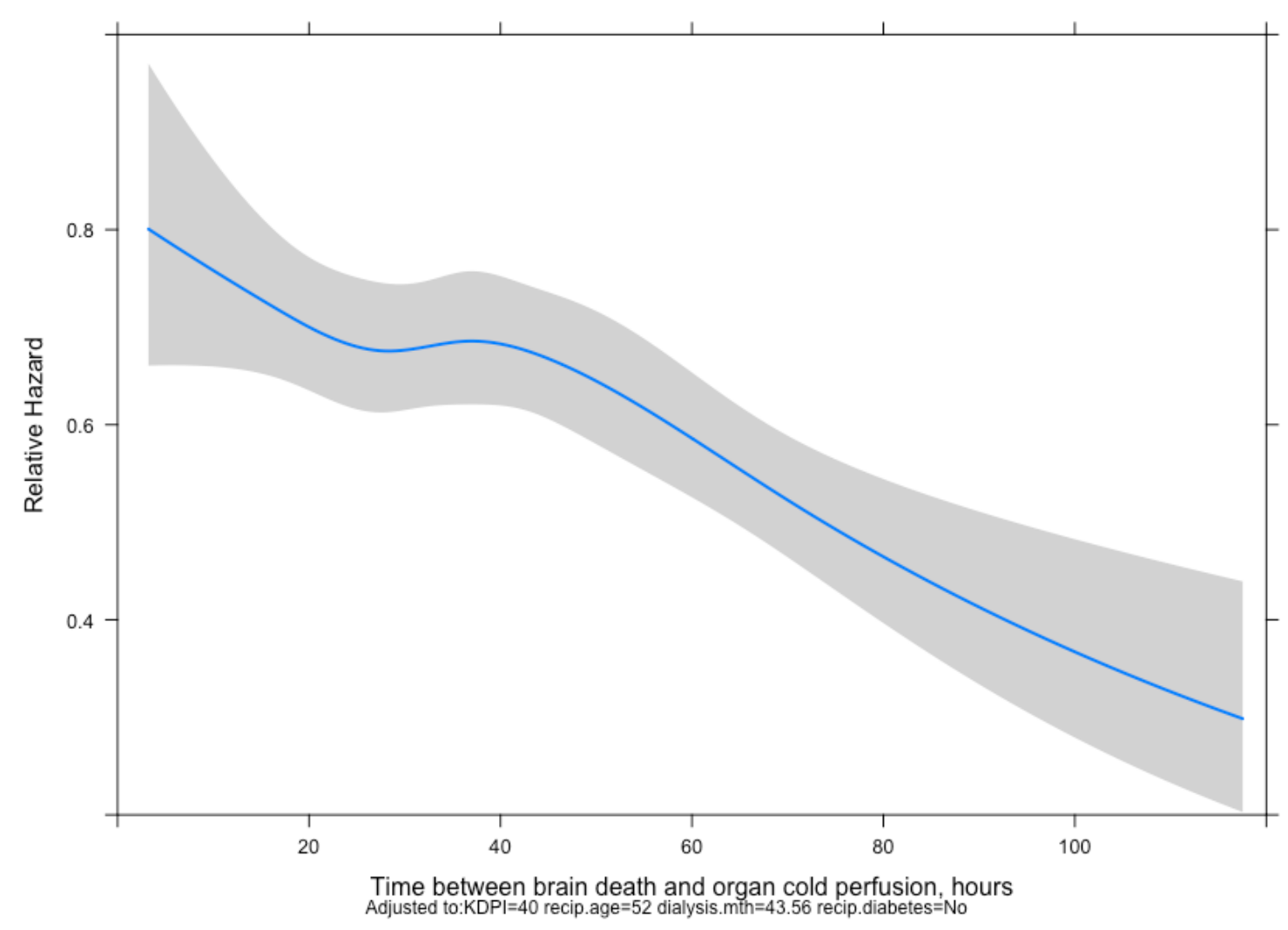

Figure 9. The relative hazard predicted from the multivariable model with a restricted cubic spline. Sensitivity analysis of cold ischemia time $<12 \mathrm{~h}$, US cohort. The predicted hazard was calculated by setting confounder values to their median (continuous variables) or the most frequent category (categorical variables) 
CIT 12-18 $\mathrm{h}$ (26799 transplantations, 5451 events): $p=0.123$ for non-linearity in the univariate model (Figure 9) and $\mathrm{p}=0.543$ in multivariable model; adjusted $\mathrm{HR}=0.963$ $(95 \% \mathrm{Cl} 0.931-0.996, p=0.030)$

US cohort, cold ischemia time $12-18$ hours

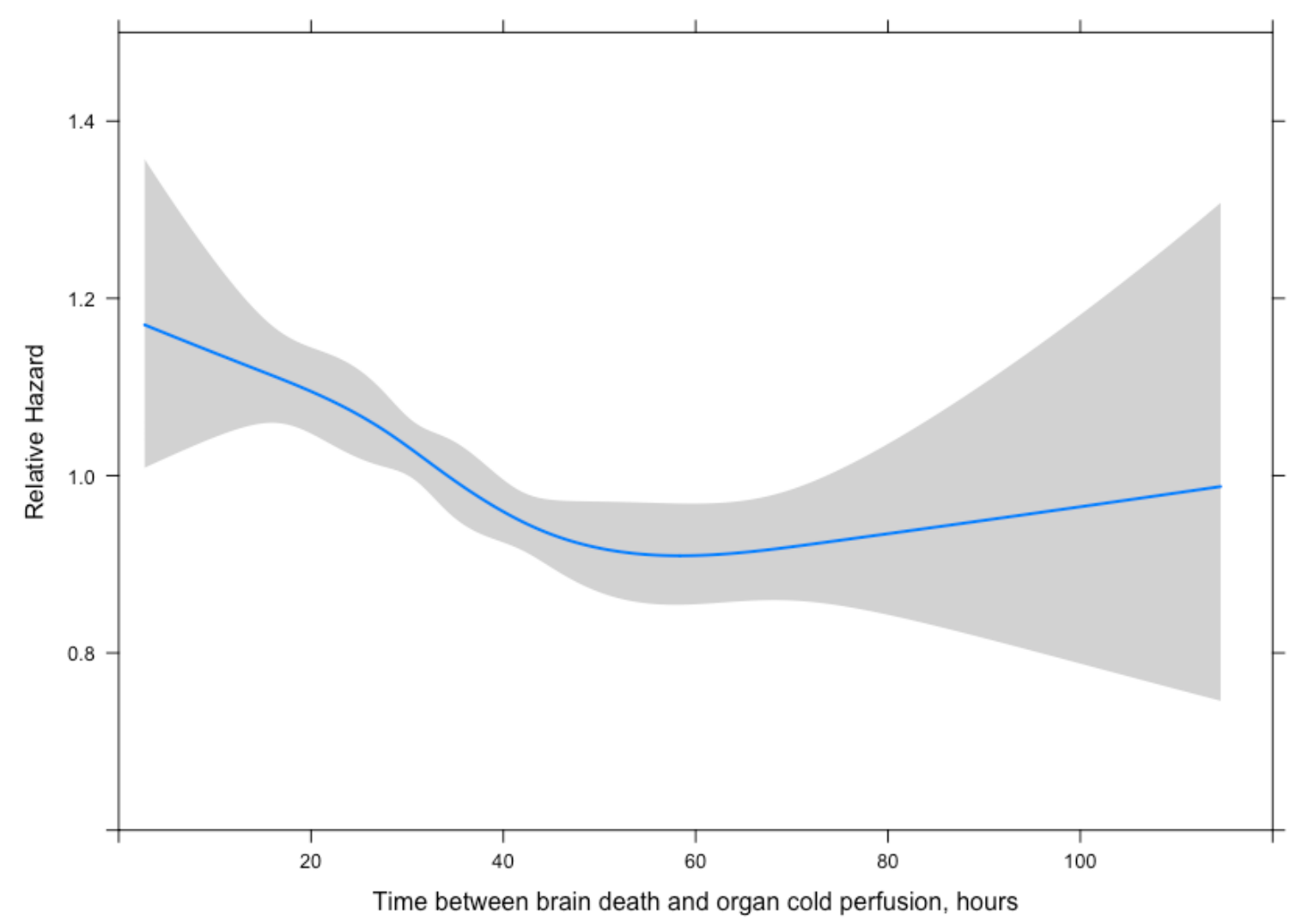

Figure 10. The relative hazard predicted from the univariate model with a restricted cubic spline. Sensitivity analysis of cold ischemia time 12 to 18 hours, US cohort. 
CIT 18-24 $\mathrm{h}$ (29378 transplantations, 2410 events): $p=0.152$ for non-linearity in the univariate model (Figure 10) and $\mathrm{p}=0.035$ in multivariable model; adjusted $\mathrm{HR}=0.927$ $(95 \% \mathrm{Cl}$ 0.891-0.965, $\mathrm{p}=0.0002)$

US cohort, cold ischemia time $18-24$ hours

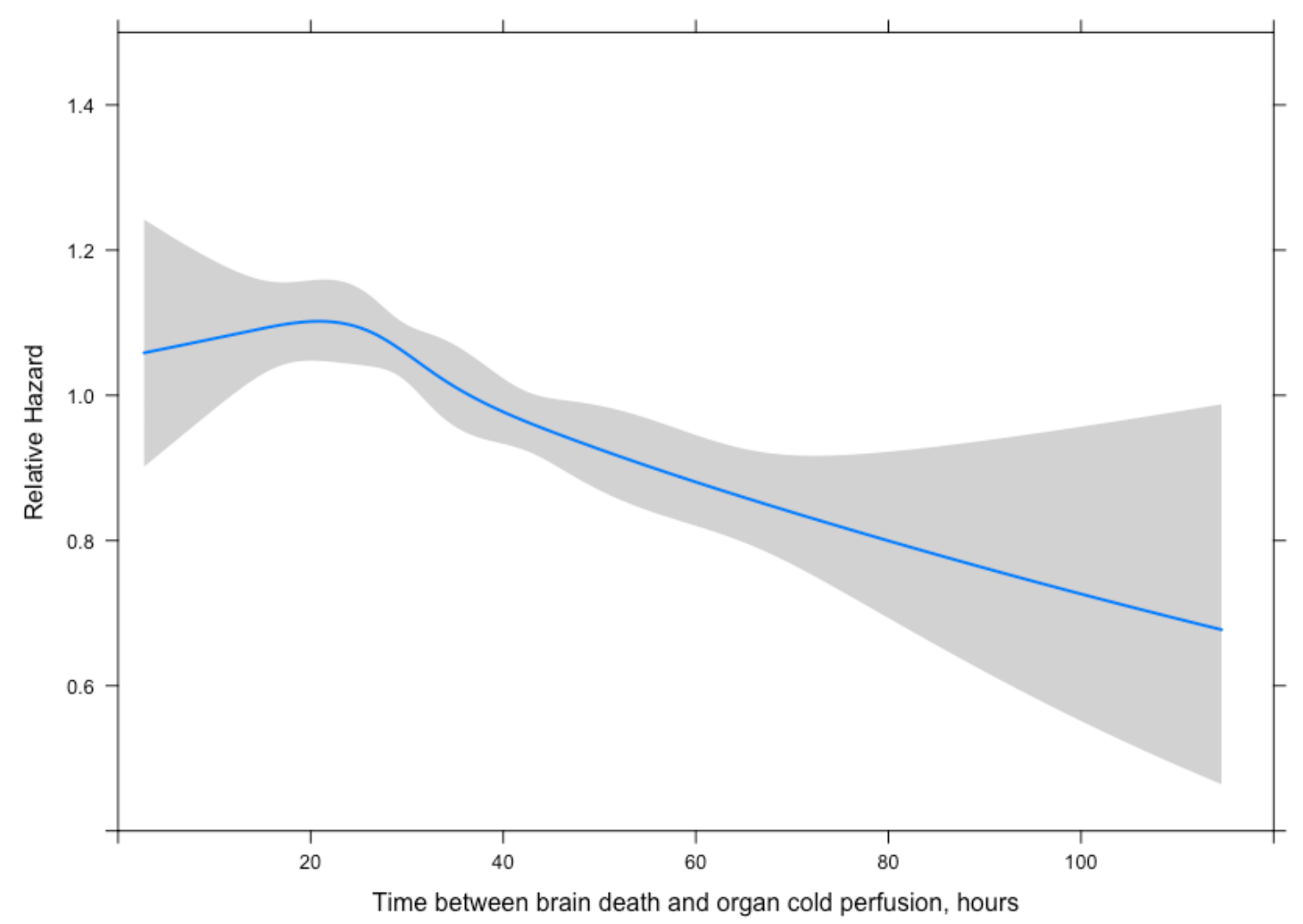

Figure 11. The relative hazard predicted from the univariate model with a restricted cubic spline. Sensitivity analysis of cold ischemia time 18 to 24 hours, US cohort. 
CIT >=24 $\mathbf{h}$ (18537 transplantations, 3980 events): $p=0.016$ for non-linearity in the univariate model (Figure 11) and $\mathrm{p}=0.489$ in multivariable model; adjusted $\mathrm{HR}=$ $0.944,95 \% \mathrm{Cl} 0.922-0.967, \mathrm{p}<0.0001$ )

US cohort, cold ischemia time $>=24$ hours

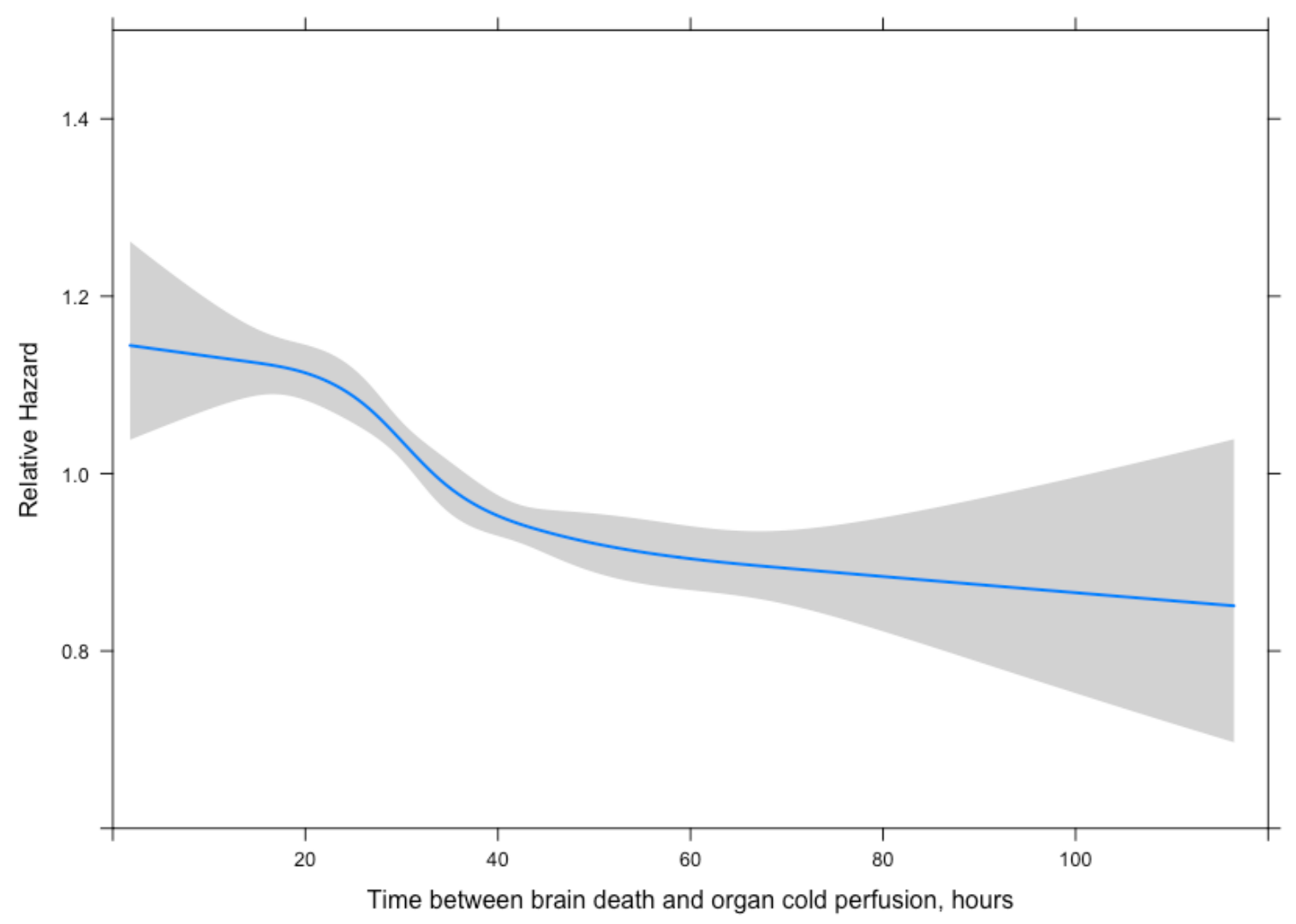

Figure 12. The relative hazard predicted from the univariate model with a restricted cubic spline. Sensitivity analysis of cold ischemia time $>=24$ hours, US cohort. 